\title{
Estrogenic and Antioxidant Activities of Pterocarpus soyauxii (Fabaceae) Heartwood Aqueous Extract in Bilateral Oophorectomized Wistar Rat
}

\author{
Yolande Sandrine Mengue Ngadena, ${ }^{1,2}$ Pascal Emmanuel Owona, ${ }^{2}$ Michel Noubom, ${ }^{3}$ \\ Michel Arnaud Mbock, ${ }^{2}$ Lohik MbolangNguegan, ${ }^{2}$ Madeleine Chantal Ngoungouré, ${ }^{2}$ \\ Rodrigue Ngapout Fifen, ${ }^{2}$ Ronald Bidingha A Goufani, ${ }^{2}$ Rivaldo Bernes Kahou Tadah, \\ Danielle Claude Bilanda, ${ }^{2}$ Pierre Kamtchouing, ${ }^{2}$ and Paul Désiré Dzeufiet Djomeni $\mathbb{D}^{2}$ \\ ${ }^{1}$ Department of Psychology, Faculty of Arts, Letters and Social Science, University of Yaoundé 1, P.O. Box 812, Yaoundé, \\ Cameroon \\ ${ }^{2}$ Department of Animal Biology and Physiology, Laboratory of Animal Physiology, Faculty of Science, University of Yaoundé 1, \\ P.O. Box 812, Yaoundé, Cameroon \\ ${ }^{3}$ Department of Biological Sciences, Faculty de Medicine and Pharmaceutical Sciences, University of Dschang, P.O. Box, 67, \\ Dschang, Cameroon
}

Correspondence should be addressed to Paul Désiré Dzeufiet Djomeni; dzeufiet@yahoo.fr

Received 20 April 2021; Accepted 17 September 2021; Published 30 September 2021

Academic Editor: Antonio Vassallo

Copyright ( 2021 Yolande Sandrine Mengue Ngadena et al. This is an open access article distributed under the Creative Commons Attribution License, which permits unrestricted use, distribution, and reproduction in any medium, provided the original work is properly cited.

\footnotetext{
Phytoestrogens are used to ease postmenopausal symptoms, a property probably due to estrogenic and antioxidant effects. Pterocarpus soyauxii (P. soyauxii) is empirically used in Cameroon to treat among others primary and secondary amenorrhea. The aim of this study is to evaluate estrogenic and antioxidant activities of $P$. soyauxii heartwood aqueous extract in bilateral oophorectomized Wistar rats. Firstly, a characterization of the extract was carried out. For that, flavonoids, phenols, and tannins levels in P. soyauxii extract were evaluated by colorimetric assays and UHPLC-MS analysis was realized. In vitro antioxidant analysis of $P$. soyauxii was conducted using DPPH, ABTS, and FRAP assays. Secondly, 2 sets of pharmacologic tests were carried out. The results revealed that $P$. soyauxii aqueous extract contains, respectively, $229.42 \pm 3.62 \mathrm{mg} \mathrm{EAG/g}, 63.42 \pm 2.16 \mathrm{mg}$ EQ/g, and $27.88 \pm 0.23 \mathrm{mg}$ ETA/g of polyphenols, flavonoids, and tannins. UHPLC-MS enabled identifying seven components including mono(2-ethylhexyl) phthalate, cembrene, $3^{\prime}, 5^{\prime}$-dimethoxy-4-stilbenol, and linoleic acid. DPPH, ABTS, and FRAP assays revealed that $P$. soyauxii extract possessed a high antioxidant activity with $\mathrm{IC}_{50}$ value of $730.20 \mu \mathrm{g} / \mathrm{mL}, 892.90 \mu \mathrm{g} / \mathrm{mL}$, and $765.75 \mathrm{mEAG} / \mathrm{g}$ of extract, respectively. In the uterotrophic assay, $P$. soyauxii extract induced significant increase of fresh uterine weight, uterine and vaginal epithelial size, and mammary glands differentiation compared to Ovx control. In the postmenopausal model, compared to the sham control, vagina and uterine dystrophies were observed in Ovx rats treated with distilled water. P. soyauxii aqueous extract expressed estrogenic-like effects on vagina and did not affect uterine epithelial height compared with vehicle groups. On the back of these vaginotrophic effects, the extract displayed antiatherogenic properties by reducing $(p<0.001) \mathrm{AI}$ and LDL cholesterol level as compared to Ovx control group. The extract at $200 \mathrm{mg} / \mathrm{kg}$ significantly prevented the increase of MDA $(p<0.01)$ level and decreased nitrites $(p<0.001)$ and GSH $(p<0.01)$ levels compared to Ovx rats. These beneficial effects are related at least in part to the presence of compound such as mono(2-ethylhexyl) phthalate, $3^{\prime}, 5^{\prime}$-dimethoxy-4-stilbenol, and linoleic acid. Overall, P. soyauxii aqueous extract exhibits estrogenic and antioxidant effects which can inhibit postmenopausal symptoms by providing vaginal stratification, improving lipid profile and insulin sensitivity, and reducing oxidative stress without side effects on the endometrium and mammary gland in 84-day Ovx rats.
} 


\section{Introduction}

Menopause is a physiological state characterized by hypoestrogenism and lead to complications including hot flashes, tachycardia, vaginal dryness, urogenital atrophy, high visceral fat, increase of body weight, cardiovascular diseases, and disruption in sex steroid feedback on gonadotropin secretion [1]. The associated decline in estrogen-related antioxidant power results in the rapid development of menopausal symptoms such as cardiovascular diseases [2]. Oxidative stress is generated by an imbalance between the production of reactive oxygen species (ROS) and antioxidant defense system [3]. It is related to many risk factors of cardiovascular diseases such as obesity, atherosclerosis, insulin resistance, hypercholesterolemia, endothelial dysfunction, and vascular inflammation [4-7]. Hormone replacement therapy (HRT) is the main line for prevention and treatment of cardiovascular diseases in postmenopausal women. Despite its many benefits, HRT has adverse side effects such as breast and endometrial cancers [8]. People also use vitamins $E$ and $C$ to manage oxidative stress in postmenopausal symptoms [9]. Nevertheless, despite their protective effects, they lose their antioxidant power through oxidation [10]. In order to cope with these adverse side effects, research has focused on alternatives to HRT. The use of phytoestrogens attracted researchers over the last few years because of their antioxidant and preventive effects on such chronic diseases like cardiovascular diseases [11]. Indeed, they possess estrogenic-like activity and provide effective and secure alternative to HRT. Several medicinal plants are used empirically to cope with primary health problems and their estrogenic activity. Among them, Erythrina poeppigiana, Rheum rhaponticum, and Anthocleista schweinfurthii are reported to mimic estrogen activities in menopausal conditions [12-14]. Nevertheless, phytoestrogens are reported to induce gastrointestinal and endometrial hyperplasia side effects [15]; thus, additional preclinical and clinical studies are required to establish the safety profiles of plant extract.

Pterocarpus soyauxii Taub which is the subject of this work belongs to Fabaceae known as the African Padauk. Existent in Cameroon, Pterocarpus soyauxii ( $P$. soyauxii) also returned to Nigeria, Gabon, and the Democratic Republic of Congo [16]. The wood and stem bark of $P$. soyauxii are empirically used to treat hypertension and diabetes. Ethnomedically, Pterocarpus species are used to treat urogenital pathologies and infertility. Moreover, pterostilbene identified in the extract of $P$. soyauxii has been reported to exhibit estrogenic activities in vitro $[17,18]$. Traditional healers of the Center Region of Cameroon assert that heartwood $P$. soyauxii maceration is used to treat primary and secondary amenorrhea and some menopausal symptoms. The main objective of the present study was to evaluate estrogenic and antioxidant activities of the aqueous extract of the heartwood of P. soyauxii in bilateral oophorectomized Wistar rats.

\section{Materials and Methods}

2.1. Chemicals. 2,2'-Azinobis-3- ethylbenzothiazoline-6sulfonic acid (ABTS), 1,1-diphenyl-2-picrylhydrazyl (DPPH), 2,4,6-tri (2-pyridyl)-s-triazine, potassium persulfate, and ascorbic acid were purchased from Sigma Chemical Co. (St. Louis, MO, USA). Diazepam (Valium ${ }^{\circledR} 10 \mathrm{mg}$ ) and $17-\beta$ estradiol valerate (Progynova ${ }^{\circledR} 2 \mathrm{mg}$ ) were purchased from DELPHRAM (Lille, France).

2.2. Plant Material. The leaves and heartwood of Pterocarpus soyauxii Taub were harvested in Ngomedzap (Center Region, Cameroon) during the rainy season at 7:30 am on April 21, 2020. These leaves were authenticated at the National Herbarium of Cameroon (HNC-IRA) by comparison with the specimen of Thomas O. W8175 deposited under the voucher number $56984 \mathrm{HNC}$.

2.2.1. Extraction. The collected Pterocarpus soyauxii heartwood pieces were air dried at room temperature for 30 days. $70 \mathrm{~g}$ of the powder obtained was macerated in $2 \mathrm{~L}$ of distilled water for 48 hours at room temperature. The macerate obtained was filtered using Whatman number 3 filter paper and the filtrate obtained was evaporated in a rotary oven at $45^{\circ} \mathrm{C}$. This process made it possible to obtain $5.6 \mathrm{~g}$ of crude extract with a yield of $8 \%$.

2.2.2. Determination of Study Doses. The recommendations of the traditional healer allowed for obtaining from $400 \mathrm{~mL}$ of macerate $1.12 \mathrm{~g}$ of crude extract after drying. The dose used in rats was determined by multiplying the HED by 6.2 according to the method described by Nair [19], resulting in a dose of approximately $100 \mathrm{mg} / \mathrm{kg}$. This dose was divided by 2 and then multiplied successively by 2 and 4 to obtain the doses of 50, 200, and $400 \mathrm{mg} / \mathrm{kg}$. The dose of $300 \mathrm{mg} / \mathrm{kg}$ was obtained by averaging the doses of 200 and $400 \mathrm{mg} / \mathrm{kg}$.

2.2.3. Phytochemical Analysis. The analysis of the phytochemical composition of the aqueous extract of the heartwood of $P$. soyauxii was carried out by using quantitative assays. Indeed, the levels of flavonoids, polyphenols, and tannins were evaluated according to Broadhurst and Jones [20], Singleton and Rossi [21], and Zhishen et al. [22], respectively.

\subsubsection{UHPLC-MS Analysis of $P$. soyauxii Extract.} UHPLC-MS analysis was used to identify the phytochemical profile of $P$. soyauxii extract in an attempt of standardization. To obtain high-resolution mass spectra of extract, a spectrometer (QTOF Bruker, Germany) equipped with a Heated Electrospray Ionization (HESI) source was used. The spectrometer operates in positive mode (mass range: $100-1500$, with a scan rate of $1.00 \mathrm{~Hz}$ ) with automatic gain control to provide high-accuracy mass measurements within 
$0.40 \mathrm{ppm}$ deviation using sodium formate as calibrant. Spray voltage of $4.5 \mathrm{kV}$ and capillary temperature of $200^{\circ} \mathrm{C}$ were used for assays. Nitrogen was used as sheath gas $(10 \mathrm{~L} / \mathrm{min})$. The spectrometer was attached to an Ultimate 3000 (Thermo Fisher, Germany) UHPLC system consisting of LC-pump, diode array detector (DAD) $(\lambda: 190-600 \mathrm{~nm})$, autosampler (injection volume $10 \mu \mathrm{L}$ ), and column oven $\left(40{ }^{\circ} \mathrm{C}\right)$. The separation was performed using a Synergi MAXRP 100A $(50 \times 2 \mathrm{~mm}, 2.5 \mu$ particle size $)$ with a $\mathrm{H}_{2} \mathrm{O}(+0.1 \% \mathrm{HCOOH})$ (A)/acetonitrile $(+0.1 \% \mathrm{HCOOH})(\mathrm{B})$ gradient (flow rate $500 \mu \mathrm{L} / \mathrm{min}$, injection volume $5 \mu \mathrm{L}$ ). The sample was analyzed using a gradient program as follows: $95 \% \mathrm{~A}$ isocratic for $1.5 \mathrm{~min}$, linear gradient to $100 \%$ B over $6 \mathrm{~min}$, after $100 \%$ $\mathrm{B}$ isocratic for $2 \mathrm{~min}$, the system returned to its initial condition (90\% A) within $1 \mathrm{~min}$ and was equilibrated for $1 \mathrm{~min}$. Based on the mass of compounds previously identified in Pterocarpus genus, identification of compounds was performed.

2.3. Animal Material. Healthy female albino Wistar rats (8-10 weeks old) weighing 120-130 g were supplied by the production facility of the Animal Physiology Laboratory, University of Yaoundé 1 (Cameroon). All rats were housed in clean plastic cages at the room temperature (natural cycle). They had free access to tap water and soy-free rat chow. The composition of animal diet was corn (60\%), bone flour (3\%), peanuts (5\%), wheat (10\%), fish flour (20\%), salt (1\%), and vitamin complex (Olivitazol) (1\%). All experiments were conducted in accordance with the principles and procedures of the European Union on Animal Care (CEE Council 86/609) guidelines adopted by the Cameroon Institutional National Ethic Committee, Ministry of Scientific Research and Technology Innovation (Reg. number FWAIRD 0001954).

\subsection{Determination in Vitro of Antioxidant Properties}

2.4.1. DPPH Radical Scavenging Assay. The DPPH free radical scavenging assay was carried out for the evaluation of the antioxidant activity. This assay measures the free radical scavenging capacity of the investigated extract. DPPH is a molecule containing a stable free radical. In the presence of an antioxidant, which can donate an electron to DPPH, the purple color typical for free DPPH radical decays and the absorbance change is measured at $517 \mathrm{~nm}$. The antiradical activity of the plant extract was examined based on the scavenging effect of the stable DPPH free radical activity [23]. Briefly, $2 \mathrm{~mL}$ of DPPH (0.1 mM prepared in methanol) was introduced into a test tube containing $0.5 \mathrm{~mL}$ of extract $(0.1$ to $1 \mathrm{mg} / \mathrm{mL})$. Then the mixture was stirred well for $5 \mathrm{~min}$ and incubated in the dark for $60 \mathrm{~min}$ at room temperature $\left(20^{\circ} \mathrm{C}\right)$. For the control tube, methanol was used in place of the extract. The reference used was ascorbic acid at concentrations of $0.1 \mathrm{mg} / \mathrm{mL}$ to $1 \mathrm{mg} / \mathrm{mL}$. A calibration curve was drawn from this reference. The antioxidant activity of the plant extract was expressed as a percentage inhibition following the relationship:

$$
\% \text { inhibition }=\frac{(\text { OD control }- \text { OD sample })}{\text { OD control }} \times 100 \text {. }
$$

The $\mathrm{IC}_{50}$ value $(\mu \mathrm{g} / \mathrm{mL})$ is the effective concentration at which DPPH radicals were scavenged by $50 \%$ and the value was obtained by interpolation from linear regression analysis.

2.4.2. Determination of Ferric-Reducing Antioxidant Power (FRAP) Assay. The assessment of ferric-reducing antioxidant power (FRAP) was performed based on the ability of the tested substance to reduce ferric tripyridyl triazine (Fe III TPTZ) complex to ferrous form (intense blue color) at low $\mathrm{pH}$ by using a modified method of Benzie and Strin [24]. The solution of TPTZ (2,4,6-tri (2-pyridyl)-s-triazine) was obtained by diluting TPTZ $(10 \mathrm{mM})$ in $10 \mathrm{ml}$ of $\mathrm{HCl}(400 \mathrm{mM}$ diluted with distilled water) and $10 \mathrm{~mL}$ of $10 \mathrm{mM}$ iron chloride $\left(\mathrm{FeCl}_{3}\right)$ solution was prepared in distilled water. FRAP reagent was obtained by mixing $100 \mathrm{~mL}$ of acetate buffer ( $\mathrm{pH} 3.6$ ) with $10 \mathrm{ml}$ of TPTZ solution and $10 \mathrm{ml}$ of iron chloride solution. In test tubes containing $2 \mathrm{~mL}$ of FRAP reagent, $75 \mu \mathrm{L}$ of sample (extract/catechin) was added and the mixture was stirred and incubated for 15 minutes. Optical densities were read at the wavelength of $593 \mathrm{~nm}$ against white.

2.4.3. ABTS Radical Scavenging Assay. To determine ABTS radical scavenging assay, the method described by $R e$ et al. [25] was used. Radical ABTS was obtained as follows: in an Erlenmeyer flask, $0.0384 \mathrm{~g}$ of ABTS and $0.00662 \mathrm{~g}$ of potassium persulfate $\left(\mathrm{K}_{2} \mathrm{~S}_{2} \mathrm{O}_{8}\right)$ were weighed and then $10 \mathrm{~mL}$ of distilled water was added. The mixture was then solubilized for $5 \mathrm{~min}$ and incubated for $16 \mathrm{~h}$ at room temperature $\left(20^{\circ} \mathrm{C}\right)$ in the dark before use. For the actual analysis, the ABTS solution was diluted with ethanol to an absorbance of 1.3 $( \pm 0.02)$ at $734 \mathrm{~nm}$ and stable at $30^{\circ} \mathrm{C}$ (initial OD). Then in a test tube, $1.8 \mathrm{~mL}$ of this diluted ABTS solution and $0.2 \mathrm{~mL}$ of extract $(1 \mathrm{mg} / \mathrm{mL})$ were introduced and shaken well. The absorbance reading was taken at $734 \mathrm{~nm}$ and the values considered were those that remained stable at room temperature for approximately 1 minute. Ascorbic acid was used as the reference antioxidant at the same concentrations as extract. The results were expressed as a percentage of inhibition and calculated according to the following formula:

$$
\% \text { inhibition }=\frac{(\text { OD control }- \text { OD sample })}{\text { OD control }} \times 100 \text {. }
$$

\subsection{In Vivo Experimental Design}

2.5.1. Effect of 3-Day Treatment with P. soyauxii. This test was performed according to the protocol described by the OCDE [26]. Forty 8-to-10-week-old female Wistar rats were used. Thirty-five of these rats were ovariectomized using a dorsal approach and 5 more underwent simulation surgery and formed the sham-operated group. 14 days after ovariectomy, the ovariectomized animals (Ovx) were randomized and then divided into 7 groups of 5 animals each for oral 
administration of treatments for 3 days. The aqueous extract of Pterocarpus soyauxii heartwood was administered at doses of 50,100,200,300, and $400 \mathrm{mg} / \mathrm{kg}$ and estradiol valerate $\left(\mathrm{E}_{2} \mathrm{~V}\right)$ was administered at a dose of $1 \mathrm{mg} / \mathrm{kg}$. A group of Ovx animals and the sham-operated group received distilled water at $10 \mathrm{~mL} / \mathrm{kg}$. At the end of the treatments, vaginal smears were carried out, and then the animals were sacrificed by decapitation under anaesthesia with diazepam and ketamine. The estrogen-dependent organs (uterus, vagina, and mammary gland) were removed and then fixed in $10 \%$ buffered formaldehyde solution for histological analysis. Before fixation, the uterus was weighed and part of it was homogenized in McEwen's solution for the evaluation of the level of uterine proteins. At last, the fresh uterine weight, uterine protein levels, and uterine and vaginal epithelial size as well as mammary gland alveolar and ductal differentiation were assessed.

2.5.2. Evaluation of Pterocarpus soyauxii Activities in a Postmenopausal Model. Thirty-five rats were either shamoperated (sham) or bilaterally ovariectomized (Ovx) like in the first experiment. Eighty-four days later, animals were distributed in seven different groups $(n=5)$ and treated per os once daily for 28 consecutive days as follows: sham and an Ovx group received distilled water, the 4 others batches received, respectively, $1 \mathrm{mg} / \mathrm{kg}$ of $\mathrm{E}_{2} \mathrm{~V}$, and $P$. soyauxii aqueous extract at 100, 200, and $300 \mathrm{mg} / \mathrm{kg}$. At day 21 , insulin tolerance test was realized. Animals were weighted weekly. Twenty-four hours after the last administration (day 29) and following a $12 \mathrm{~h}$ of overnight fasting, animals were sacrificed under light anaesthesia. Blood samples were taken and centrifuged at $3500 \mathrm{~g}\left(15 \mathrm{~min}\right.$ at $\left.4^{\circ} \mathrm{C}\right)$ to obtain serum samples which were kept at $-15^{\circ} \mathrm{C}$ for the determination of total cholesterol (TC), triglycerides (TG), and high-density cholesterol (HDL-C) levels. The concentration of lowdensity lipoproteins cholesterol (LDL-C) and very-lowdensity lipoproteins (VLDL) levels was calculated using the Friedewald equation [27]. Uterus, vagina, and aorta were dissected out and cleaned of all soft tissues. Prior to immersion-fixation of organs in the formaldehyde $10 \%$ buffered for histological analysis, they were weighted. A portion of aorta was homogenized in Mac even buffer to evaluate antioxidant parameters. Abdominal fat of each animal was weighted.

2.6. Vaginal Cellular Differentiation. Vaginal smears were carried out at the end of the experiment using an eyedropper containing $10 \mu \mathrm{L}$ of $\mathrm{NaCl} 0.9 \%$, placed on ringed slides, fixed, and coloured with Papanicolaou method [28]. Cellular differentiation was observed under a light microscope at $\times 100$ magnification.

2.7. Insulin Tolerance Test (ITT) in Ovariectomized Rats. Prior to an ITT test, rats were fasted for $12 \mathrm{~h}$. A single dose of insulin at a dose of $2 \mathrm{UI} / \mathrm{kg}$ was injected i.p. into each rat. Blood samples were taken from tail veins and the blood sugar levels were measured using the Accu-chek reactive strips at 0 (just before the insulin injection), 10, 20, 30, and $60 \mathrm{~min}$ after injection of insulin.

2.8. Determination of Relative Weight of Organs. The relative fresh weight of uterus, abdominal fat, and aorta was calculated using the following formula according to [29]:

$$
\text { Organ weight ratio }=\frac{\text { Uterus Weight }(\mathrm{g})}{\text { Body weight }(\mathrm{g})} \times 100 .
$$

2.9. Assays for Lipid Profile. Serum total cholesterol (TC), triglycerides (TG), and HDL cholesterol (HDL-C) levels were assessed using commercial diagnostic kits Fortress, UK. The levels of LDL cholesterol (LDL-C) were assessed by using the following formula: LDL-Chol $(\mathrm{mg} / \mathrm{dL})=\mathrm{Chol}-$ (TG/5) - HDL-Chol. VLDL cholesterol (VLDL-C) level was calculated with the following formula: TG/5 [27]. Atherogenic index (AI) was calculated as TC on HDL-C.

2.10. Oxidative Stress Parameters Investigation. Malondialdehyde (MDA) and reduced glutathione (GSH) in aorta homogenate were determined using the methods described by Wilbur et al. [30] and Ellman [31], respectively, while the nitrites content was determined using the method described by Green et al. [32].

2.11. Histomorphometric Analysis of Uterine, Vaginal, and Aorta Tissues. Aortic, uterine, vaginal, and mammary gland tissues after fixation ( 2 weeks) in formaldehyde $10 \%$ buffered were trimmed and dehydrated in alcohol of croissant gradient $(70 \%, 80 \%, 90 \%$, and $100 \%$ (3 baths)). After tissues were clarified in 2 baths of xylene ( $1 \mathrm{~h} 30 \mathrm{~min}$ per bath) and impregnated in liquid paraffin at $60^{\circ} \mathrm{C}$ (for 5 hours), uterine and vaginal epithelial sizes as well as intima and media heights were assessed from $5 \mu \mathrm{m}$ sections of paraffin-embedded and haematoxylin-eosin stained uterine and vaginal tissues. Epithelial sizes were assessed on microphotographies obtained by using a light microscope (Leitz wetzlar Germany 513) connected with a digital camera celestron 44421 linked to a computer where images were transferred.

2.12. Statistical Analysis. Data were expressed as mean\pm standard error on mean. Statistical analysis was performed using one-way analysis of variance (ANOVA) followed by the Tukey post hoc test using GraphPad Prism 8.0.1. A value of $p \prec 0.05$ was considered statistically significant.

\section{Results}

3.1. Phytochemical Analysis. The phytochemical analysis revealed that heartwood of Pterocarpus soyauxii extract contains, respectively, $229.42 \pm 3.62 \mathrm{mg}$ EAG/g, $63.42 \pm 2.16 \mathrm{mg} \mathrm{EQ} / \mathrm{g}$, and $27.88 \pm 0.23 \mathrm{mg}$ ETA/g of polyphenols, flavonoids, and tannins (Table 1). 
TABLe 1: Phytochemical analysis of P. soyauxii aqueous extract.

\begin{tabular}{lc}
\hline Secondary metabolites & Aqueous extract of Pterocarpus soyauxii heartwood \\
\hline Flavonoids (mg EQ/g) & $63.42 \pm 2.16$ \\
Polyphenols (mg EAG/g) & $229.42 \pm 3.62$ \\
Tannins (mg ETA/g) & $27.88 \pm 0.23$
\end{tabular}

$\mathrm{mg} \mathrm{ETA} / \mathrm{g}=\mathrm{mg}$ equivalent of tannic acid per gram of extract. $\mathrm{mg} \mathrm{EGA} / \mathrm{g}=\mathrm{mg}$ equivalent of gallic acid per gram of extract. $\mathrm{mg} \mathrm{EQ} / \mathrm{g}=\mathrm{mg}$ equivalent of quercetin per gram of extract.

3.2. Identification of Compounds of P. soyauxii Extract by UHPLC-MS Analysis. Ultra-High-Performance Light Chromatography allowed the separation of components of the aqueous extract of Pterocarpus soyauxii. Ions mass spectrometry and a representative base peak chromatogram are shown in Figure 1 and Table 2. UHPLC-MS enabled identifying seven components: ambrial, 7-O-acetylformononetin, khrinone $\mathrm{A}$, mono(2-ethylhexyl) phthalate, cembrene, $3^{\prime}, 5^{\prime}$-dimethoxy-4-stilbenol, and linoleic acid.

3.3. In Vitro Antioxidant Activity. According to the results obtained in Table 3, vitamin C exhibits greater anti-free radical activity than that of our extract. It had the smallest $\mathrm{IC}_{50}$ against the DPPH and ABTS radicals. The inhibitory concentration 50 of vitamin $\mathrm{C}$ was $24.56 \mu \mathrm{g} / \mathrm{mL}$ while the aqueous extract of $P$. soyauxii was $730.20 \mu \mathrm{g} / \mathrm{mL}$ for the DPPH radical while it was 37.75 for vitamin C against 892.90 for the extract of PS for the radical ABTS. The concentration of FRAP was $765.75 \mathrm{mEAG} / \mathrm{g}$.

\subsection{Effects of a 3-Day Treatment with P. soyauxii}

3.4.1. Effect on Relative Weight, Protein Level, and the Size of the Epithelium of Uterus. Figure 2 represents effects of 3-day treatment with aqueous extract of $P$. soyauxii heartwood on the relative weight of the uterus (Figure 2(a)), the size of the uterine epithelium (Figure 2(b)), and uterine protein level (Figure 2(c)). The extract induced a significant increase in the relative weight of the uterus and the size of the uterine epithelium at the doses of 200 and $300 \mathrm{mg} / \mathrm{kg}$ with respective probabilities of $p<0.001$ and $p<0.01$ as compared to the ovariectomized animals treated with distilled water. Figure 2(c) also shows that the extract induced a significant increase in uterine protein levels $(p<0.05)$ at doses of 100 and $400 \mathrm{mg} / \mathrm{kg}$. The doses of 200 and $300 \mathrm{mg} / \mathrm{kg}$ also significantly increased this uterine protein level $(p<0.001)$ in comparison to animals in the Ovx control.

3.4.2. Effect on the Size of the Vagina Epithelium. According to Figure 3, the histomorphometry of vaginal histological sections showed a significant $(p<0.001)$ increase in the size of the vaginal epithelium at the doses of 200 and $300 \mathrm{mg} / \mathrm{kg}$ and significant decrease in the size of the vaginal epithelium at a dose of $400 \mathrm{mg} / \mathrm{kg}$.

3.4.3. Effect on Vaginal Cytology and Microarchitecture of Vagina, Uterus, and Mammary Gland. Figure 4 represents effects of 3-day treatment with aqueous extract of $P$. soyauxii heartwood on the vaginal cytology and microarchitecture of vaginal, uterus, and mammary gland. The three-day treatment with the aqueous extract of $P$. soyauxii heartwood 14 days after ovariectomy resulted in the appearance of superficial cells on vaginal smears of female rats treated with the extract at the doses of $100,200,300$, and $400 \mathrm{mg} / \mathrm{kg}$ as well as estradiol valerate. However, the vaginal smear of the rats treated with the extract at a dose of $50 \mathrm{mg} / \mathrm{kg}$ revealed parabasal, polynuclear, and some superficial cells, which indicate a cycle at the metestrus stage. According to Figure 4, the 3-day treatment with plant extract and $\mathrm{E}_{2} \mathrm{~V}$ resulted in stratification of the vaginal epithelium at doses of 200 and $300 \mathrm{mg} / \mathrm{kg}$ compared with that of Ovx group animals treated with distilled water. On the mammary gland, $P$. soyauxii aqueous extract at doses of 100,200 , and $300 \mathrm{mg} / \mathrm{kg}$ like $\mathrm{E}_{2} \mathrm{~V}$ compared to Ovx animals induced a differentiation of the cell layers of the acinus, an increase of eosinophilic secretions in the lumen of the acini, and heights lobule in Ovx rats. The microphotographies of uterus shows a differentiation of the endometrium with both estradiol valerate and the extract at doses of 200 and $300 \mathrm{mg} / \mathrm{kg}$ compared to the Ovx group.

\subsection{P. soyauxii Activities in a Postmenopausal Model}

3.5.1. Effects on the Vaginal Epithelium. According to Figure 5(a), the 28-day treatment with plant extract resulted in stratification of the vaginal epithelium at the doses of 200 and $300 \mathrm{mg} / \mathrm{kg}$ compared with that of Ovx group animals treated with distilled water. In addition, the histomorphometry of vaginal histological sections shows a significant $(p<0.01)$ increase in the height of the vaginal epithelium height doses of $200 \mathrm{mg} / \mathrm{kg}$. The dose of $300 \mathrm{mg} / \mathrm{kg}$ induced a significant $(p<0.001)$ increase in the size of the vaginal epithelium.

3.5.2. Effects on the Uterine Epithelium. The 28-day treatment with the extract of $P$. soyauxii did not have any effect on uterine epithelium at all doses. As shown by Figure 6, the uterine epithelium is simple cubic in all rats treated with the extract of $P$. soyauxii contrary to the one treated with estradiol valerate which is stratified.

3.5.3. Effects on the Mammary Gland. As shown by Figure 7, $P$. soyauxii at $100 \mathrm{mg} / \mathrm{kg}$ exhibits a cell differentiation and production of eosinophilic secretions according to Figure 8. Nevertheless, this differentiation is weaker than $\mathrm{E}_{2} \mathrm{~V}$ one. 


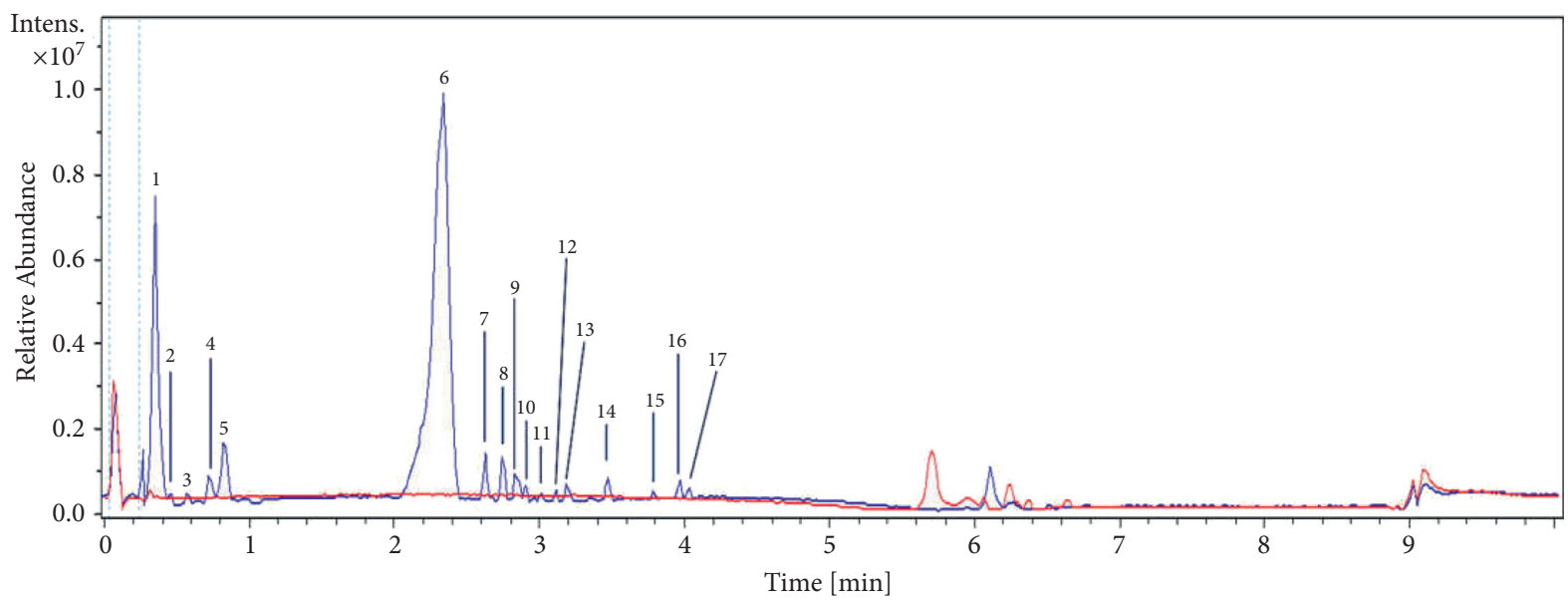

_ SP_GB3_01_4057.d: BPC+ All MS

— BlankA CN4_RA1_01_4000.d: BPC + All MS

FIgUre 1: Chromatographic profile of Pterocarpus soyauxii aqueous extract.

TABLe 2: Main signals exhibited in the LC-MS spectra of compounds detected in Pterocarpus soyauxii and proposed attribution.

\begin{tabular}{|c|c|c|c|c|c|c|}
\hline \multirow{2}{*}{$\mathrm{N}^{\circ}$} & \multirow{2}{*}{$\operatorname{Tr}(\min )$} & \multicolumn{2}{|c|}{$[M+\mathrm{H}]^{+}$} & \multirow{2}{*}{ Molecular formula } & \multirow{2}{*}{ Name of compound } & \multirow{2}{*}{ Molecular classes } \\
\hline & & Exp. & Calcl. & & & \\
\hline 1 & 0.4 & 235.2035 & 235.2056 & $\mathrm{C}_{16} \mathrm{H}_{27} \mathrm{O}$ & Ambrial & - \\
\hline 2 & 0.5 & 215.0544 & 215.0550 & $\mathrm{C}_{9} \mathrm{H}_{11} \mathrm{O}_{6}$ & Not identified & - \\
\hline 3 & 0.6 & 311.0875 & 311.0914 & $\mathrm{C}_{18} \mathrm{H}_{15} \mathrm{O}_{5}$ & 7-O-Acetylformononetin & Isoflavone \\
\hline 4 & 0.7 & 301.0738 & 301.0707 & $\mathrm{C}_{16} \mathrm{H}_{13} \mathrm{O}_{6}$ & Khrinone A & Isoflavonoid \\
\hline 5 & 0.8 & 181.1063 & 181.1071 & $\mathrm{C}_{7} \mathrm{H}_{17} \mathrm{O}_{5}$ & Not identified & - \\
\hline 6 & 2.4 & 195.1223 & 195.1227 & $\mathrm{C}_{8} \mathrm{H}_{19} \mathrm{O}_{5}$ & Ammoniated polyethylene glycol & - \\
\hline 7 & 2.6 & 279.1609 & 279.1591 & $\mathrm{C}_{16} \mathrm{H}_{23} \mathrm{O}_{4}$ & Mono(2-ethylhexyl) phthalate & Aromatic dicarboxylic acid \\
\hline 8 & 2.8 & 437.2909 & 437.2898 & $\mathrm{C}_{25} \mathrm{H}_{41} \mathrm{O}_{6}$ & Not identified & - \\
\hline 9 & 2.9 & 273.2577 & 273.2577 & $\mathrm{C}_{20} \mathrm{H}_{33}$ & Cembrene A & Diterpene \\
\hline 10 & 2.9 & 305.1074 & 305.1078 & $\mathrm{C}_{9} \mathrm{H}_{21} \mathrm{O}_{11}$ & Not identified & - \\
\hline 11 & 3.0 & 209.1507 & 209.1536 & $\mathrm{C}_{13} \mathrm{H}_{21} \mathrm{O}_{2}$ & Not identified & - \\
\hline 12 & 3.1 & 211.1301 & 211.1329 & $\mathrm{C}_{12} \mathrm{H}_{19} \mathrm{O}_{3}$ & Not identified & - \\
\hline 13 & 3.2 & 293.2127 & 293.2111 & $\mathrm{C}_{18} \mathrm{H}_{29} \mathrm{O}_{3}$ & Not identified & - \\
\hline 14 & 3.5 & 257.1210 & 257.1172 & $\mathrm{C}_{16} \mathrm{H}_{17} \mathrm{O}_{3}$ & $3^{\prime}, 5^{\prime}$-Dimethoxy-4-stilbenol & Stilbenoid \\
\hline 15 & 3.8 & 281.2495 & 281.2474 & $\mathrm{C}_{18} \mathrm{H}_{33} \mathrm{O}_{2}$ & Linoleic acid & Fatty acid \\
\hline 16 & 4.0 & 235.2054 & 235.2056 & $\mathrm{C}_{16} \mathrm{H}_{27} \mathrm{O}$ & Not identified & - \\
\hline 17 & 4.1 & 263.2378 & 263.2369 & $\mathrm{C}_{18} \mathrm{H}_{31} \mathrm{O}$ & Not identified & - \\
\hline
\end{tabular}

TABLE 3: Inhibitory concentration 50 of $P$. soyauxii aqueous extract against DPPH and ABTS radicals and FRAP concentration.

\begin{tabular}{lccc}
\hline Parameters substances & FRAP $(\mathrm{mEAG} / \mathrm{g})$ & $\mathrm{IC}_{50}$ of $\mathrm{DPPH}(\mu \mathrm{g} / \mathrm{mL})$ & $\mathrm{IC}_{50}$ of $\mathrm{ABTS}(\mu \mathrm{g} / \mathrm{mL})$ \\
\hline Vitamin C & - & 24.56 & 37.75 \\
PS extract & 765.79 & 730.20 & 892.90 \\
\hline
\end{tabular}

3.5.4. Effects on Weight Gain and Abdominal Fat. Figure 8(a) shows a significant increase in weight gain on days 7 and 14 of treatment, respectively, of $p<0.01$ and $p<0.05$ in ovariectomized rats compared with sham-operated animals. Likewise, Figure $7(\mathrm{~b})$ shows a significant increase $(p<0.001)$ in the relative weight of abdominal fat in ovariectomized rats treated with distilled water compared to sham-operated rats. The extract of $P$. soyauxii at the dose of $300 \mathrm{mg} / \mathrm{kg}$ induced a significant decrease $(p<0.05)$ in weight gain on 14 and 21 days of treatment and the same effect $(p<0.001)$ on relative weight abdominal fat compared to Ovx animals. Extract at the dose of $200 \mathrm{mg} / \mathrm{kg}$ decreased only relative weight abdominal fat $(p<0.001)$ and weight gain on 21 days of treatment compared to Ovx animals.

3.5.5. Effects on Serum Glucose Levels during Insulin Resistance Test. Figure 9 below shows a significant increase in serum glucose levels of $(p<0.01)$ and $(p<0.001)$, respectively, at 20 and 30 minutes in ovariectomized rats compared to sham-operated rats. The extract of $P$. soyauxii at the dose of $200 \mathrm{mg} / \mathrm{kg}$ resulted in a significant decrease in serum 


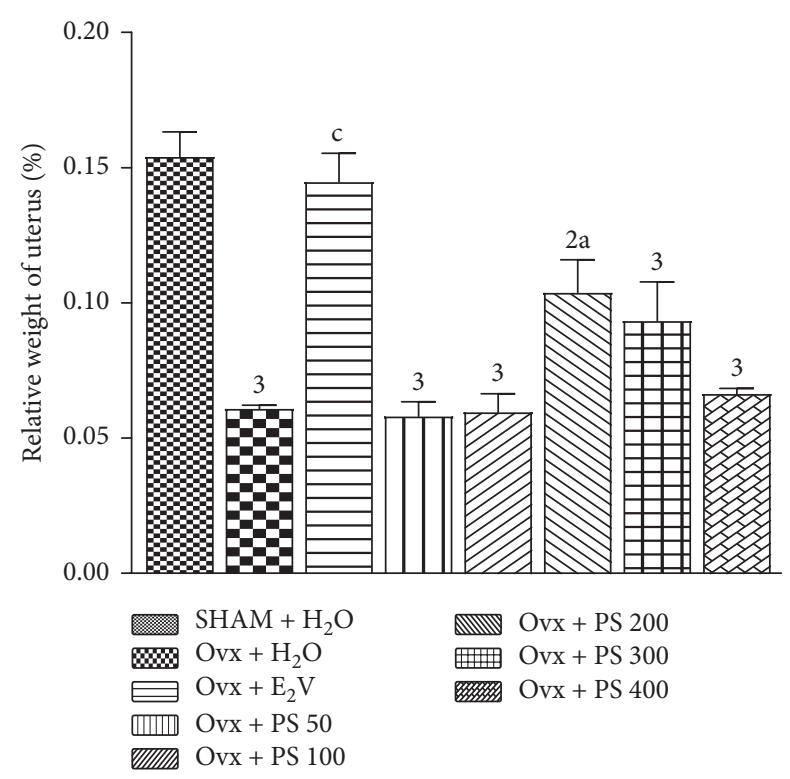

(a)

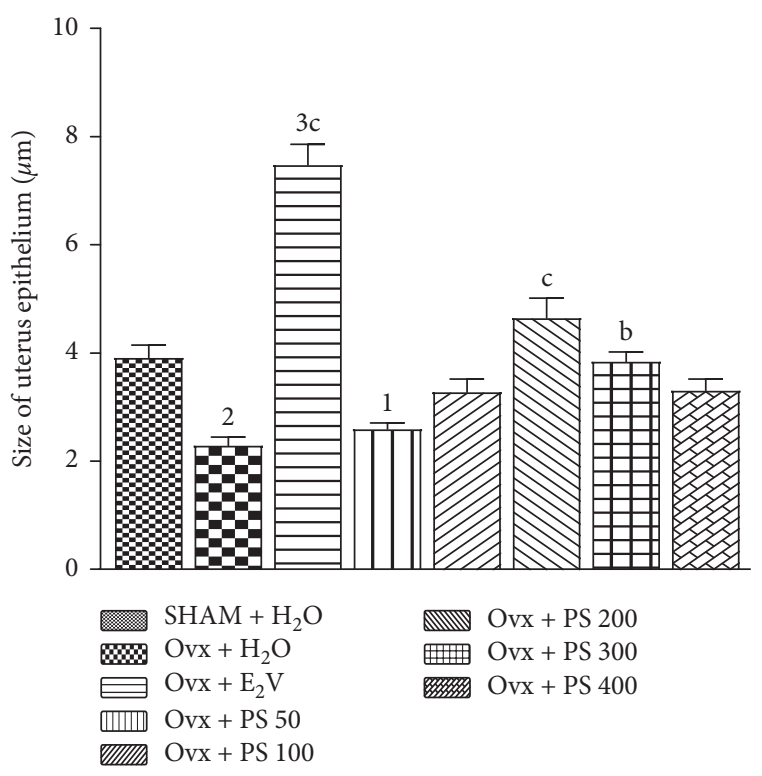

(b)

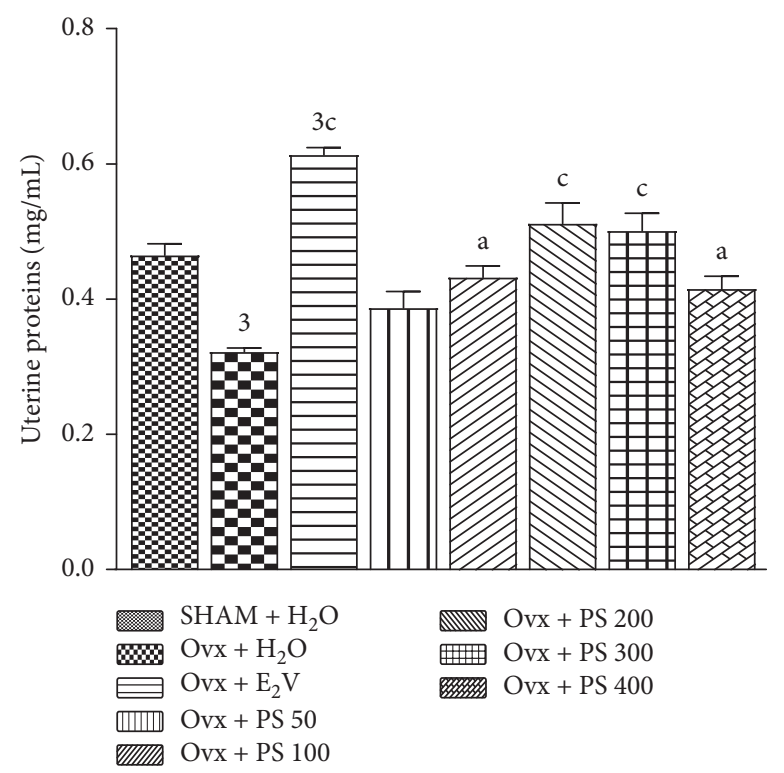

(c)

Figure 2: Effects of a 3-day treatment with P. soyauxii on relative weight of fresh uterus. (a) Size of uterine epithelium. (b) Total uterine protein levels. (c). ${ }^{1} \mathrm{p}<0.05 ;{ }^{2} p<0.01 ;{ }^{3} p<0.001$, significant difference compared to sham-operated control; ${ }^{\mathrm{a}} p<0.05 ;{ }^{\mathrm{b}} p<0.01 ;{ }^{\mathrm{c}} p<0.001$, significant difference compared to Ovx control rats. PS $=P$. soyauxii.

glucose levels at 20 and 30 minutes of $p<0.01$ and $p<0.001$, respectively, as compared to Ovx animals. The extract at the dose of $300 \mathrm{mg} / \mathrm{kg}$ resulted also in a significant decrease in serum glucose levels at 20 and 30 minutes of $p<0.05$ and $p<0.01$, respectively, as compared to Ovx animals.

3.5.6. Effects on Relative Weight of the Aorta and on Aortic Protein. Figure 10 shows a significant decrease $(p<0.05)$ in the aortic protein. There was also a significant $(p<0.05)$ increase in the relative weight of the aorta in Ovx rats as compared to sham-operated rats (Figure 10(a)). The extract of $P$. soyauxii at the dose of $300 \mathrm{mg} / \mathrm{kg}$ resulted in a significant increase $(p<0.001)$ in aortic protein levels and a significant decrease $(p<0.001)$ in relative weight of this organ. P. soyauxii extract at the doses of 100 and $200 \mathrm{mg} / \mathrm{kg}$ significantly increased protein levels $(p<0.001)$ but had no effect on relative aortic weight.

3.5.7. Effects of $P$. soyauxii on Serum Lipid Levels. Ovariectomy caused a substantial increase in the TC, TG, LDL-C, and VLDL-C levels (Table 4) and also caused substantial decrease in HDL-C levels and increase in atherogenic index as compared to sham-operated control group $(p<0.001)$. In Ovx rats, treatment with $100 \mathrm{mg} / \mathrm{kg} /$ day of $P$. 


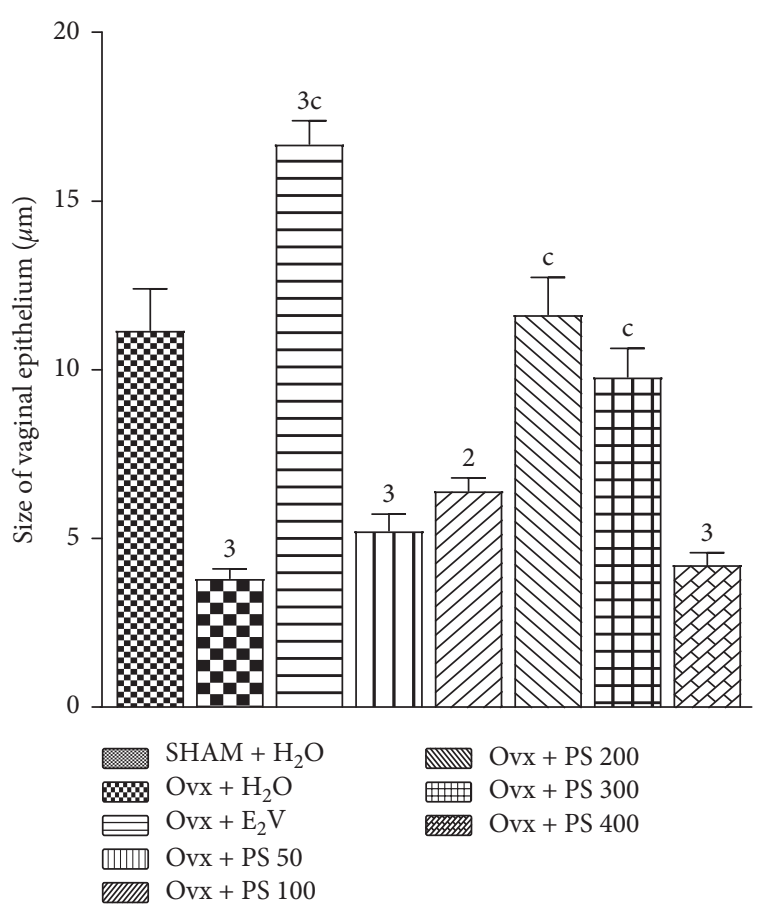

Figure 3: Effect of a 3-day treatment with $P$. soyauxii on vaginal epithelium. ${ }^{2} p<0.01 ;{ }^{3} p<0.001$, significant difference compared to sham-operated control; ${ }^{c} p<0.001$, significant difference compared to Ovx control. $\mathrm{PS}=P$. soyauxii.

soyauxii induced a significant decrease in TG, LDL-C, and VLDL-C levels and atherogenic index $(p<0.05, p<0.001$, $p<0.001$, and $p<0.05$ ) but did not affect HDL-C and TC levels compared with the Ovx-control group. P. soyauxii at the dose of $200 \mathrm{mg} / \mathrm{kg} /$ day has significantly reduced TC, TG, LDL-C, and VLDL-C levels and atherogenic index $(p<0.01$, $p<0.001, p<0.001, p<0.001$ and $p<0.001)$ and increased HDL-C levels $(p<0.05)$ as compared to Ovx-control group. At the dose of $300 \mathrm{mg} / \mathrm{kg} /$ day, $P$. soyauxii extract significantly decreased TG, LDL-C, and VLDL-C levels and atherogenic index $(p<0.001, p<0.001, p<0.001$, and $p<0.001)$ and significantly increased HDL-C levels $(p<0.05)$ as compared to Ovx group.

3.5.8. Effects of P. soyauxii on Oxidative Stress Status. After 84 days, ovariectomy resulted in a significant increase $(p<0.001)$ in MDA level and a significant decrease $(p<0.001)$ in GSH and nitrite levels in the aorta. The plant at the dose of $100 \mathrm{mg} / \mathrm{kg}$ significantly increases the levels of nitrites but had no effect on the level of GSH and MDA. $P$. soyauxii extract at the dose of 200 and $300 \mathrm{mg} / \mathrm{kg}$ significantly decreased $(p<0.001, p<0.01$, resp.) the MDA level and likewise increased $(p<0.001, p<0.01$, resp.) GSH and nitrites levels (Figure 11).

3.5.9. Effects of P. soyauxii on Aorta Histology. As shown in Figure 12, after 84 days, ovariectomy induced leukocyte infiltration in aorta compared to sham-operated rats. Leucocyte infiltration was associated with a high ratio intima/ media $(p<0.001)$ in Ovx rats. The extract at the dose of 100 , 200 , and $300 \mathrm{mg} / \mathrm{kg}$ prevented leukocyte infiltration on aorta sections. Furthermore, $P$. soyauxii extract significantly reduced at all doses the ratio intima/media in Ovx rats compared to the control group treated with distilled water.

\section{Discussion}

The aim of the present study was to assess estrogenic and antioxidant activities of aqueous extract of $P$. soyauxii heartwood in a model of oophorectomy in Wistar rats. For this, a 3-day uterotrophic assay according to the protocol of the Organization for Economic Cooperation and development [26] was used to verify estrogenic potential of the extract in ovariectomized rats. In vitro antioxidant capacity of $P$. soyauxii heartwood was evaluated using protocols described by numerous authors [23-25]. Then, an 84-day postoophorectomy model was used as described in numerous studies $[13,14]$ to assess properties of the plant extract on postmenopausal cardiovascular disorders and aortic oxidative stress. Compared to Ovx control, results of the 3-day uterotrophic assay showed that aqueous extract of $P$. soyauxii heartwood at 200 and $300 \mathrm{mg} / \mathrm{kg}$ exhibited uterotrophic activities characterized by an increase of relative weight, epithelial height, and protein level of the uterus. Plant extract also leaded to vagina cornification and stratification correlated with an increase of vaginal epithelium height and the density of foliaceous cells. The uterotrophic assay also showed an increased eosinophilic secretion in lumen of mammary acini at 200 and $300 \mathrm{mg} / \mathrm{kg}$. Indeed, it is histologically known that oophorectomy leads to atrophy of estrogen-dependent tissues like a decrease of vaginal and uterine epithelia heights; it also reduced eosinophilic secretions in the lumen of mammary acini [33-35]. Estrogenic activities of $P$. soyauxii extract could be due to flavonoids found in the plant extract $(63.42 \pm 2.16$ quercetin equivalent). As a matter of fact, flavonoids represent the most potent phytoestrogen family [36]. The results of in vitro antioxidant assay showed that $P$. soyauxii extract has induced inhibition of the DPPH and ABTS free radical with IC $_{50}$ of 730.20 and $892.90 \mu \mathrm{g} / \mathrm{mL}$, respectively. This antioxidant activity could be linked to the richness of the plant extract in phenolic compounds and linoleic acid according to LC-MS analysis. Indeed, linoleic acid can prevent the production of ROS by protecting membranes composed of 1-palmitoyl 2-linoleoyl phosphatidylcholine [37]. Besides, purslane leaves like $P$. soyauxii aqueous extract exhibit antioxidant-like properties due to phenols and linoleic acid [38].

These estrogenic and antioxidant activities of $P$. soyauxii extract can be beneficial for deep hypoestrogenism observed in postmenopausal women. Indeed, oophorectomy leads to a reduction in circulating estrogen levels [39]. In rats, longterm oophorectomy is an appropriate experimental research model to study postmenopausal disorders [40] such as atrophy of estrogen-dependent tissues, cardiovascular risk factors primarily obesity, and dyslipidaemia [41, 42]. In this study, compared to sham-operated group, 84-days oophorectomy resulted in an atrophy of estrogen- 

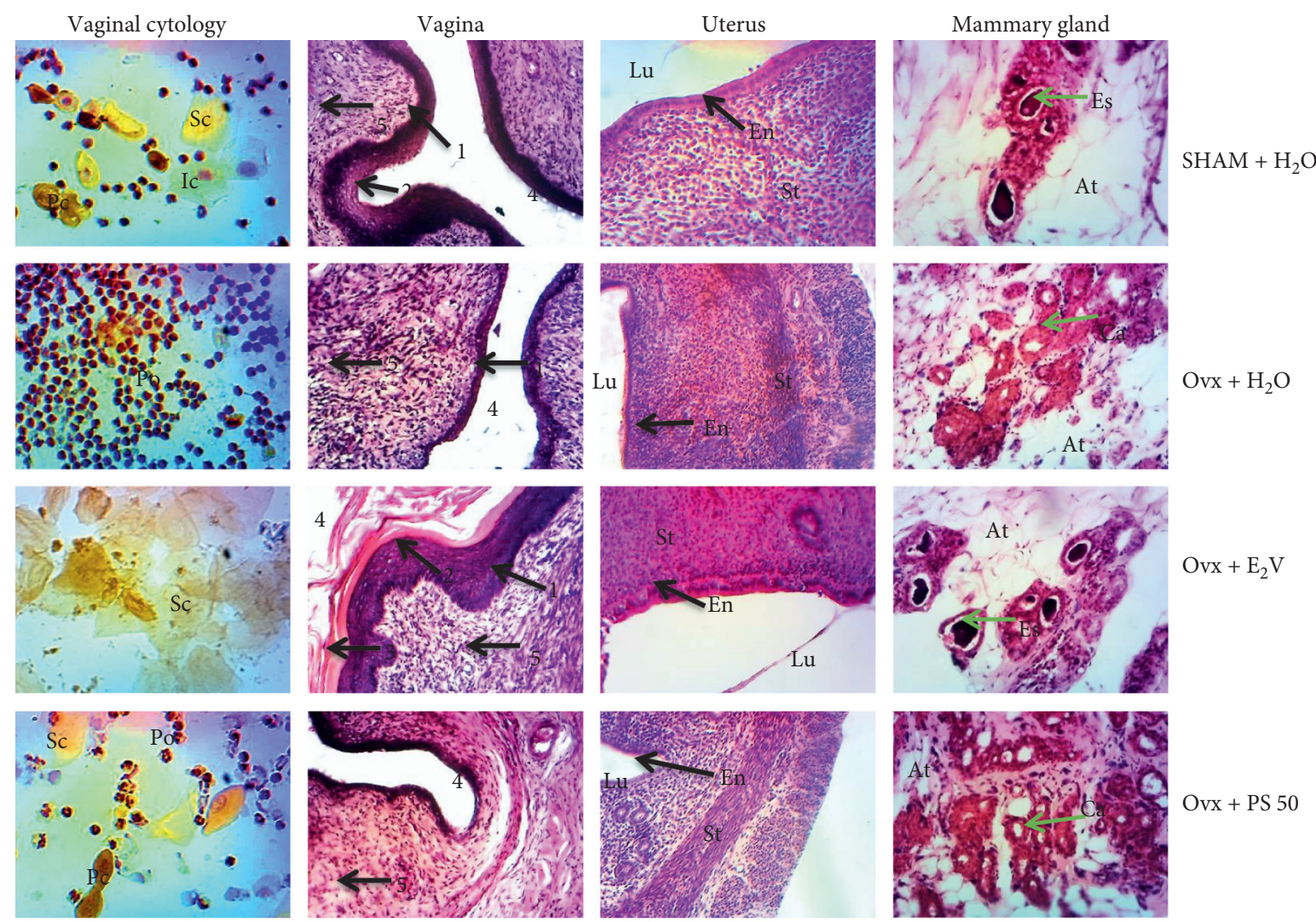

Ovx + PS 50
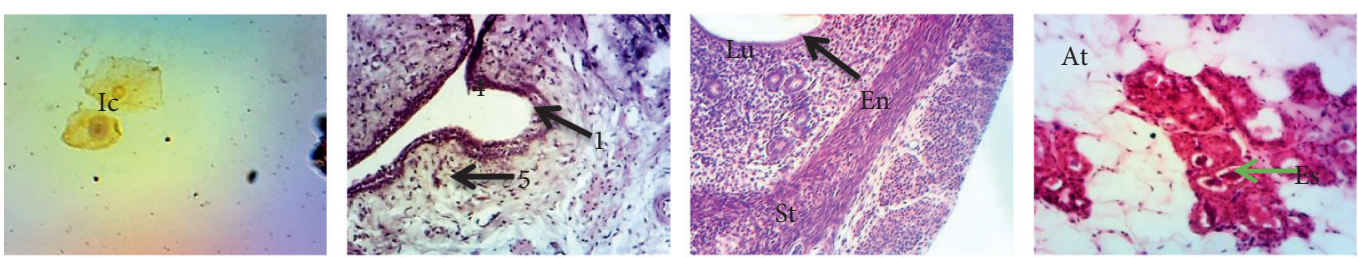

Ovx + PS 100
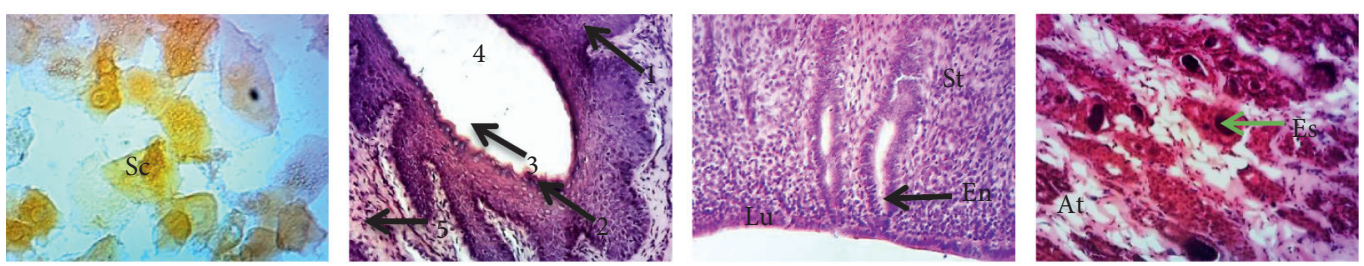

Ovx + PS 200
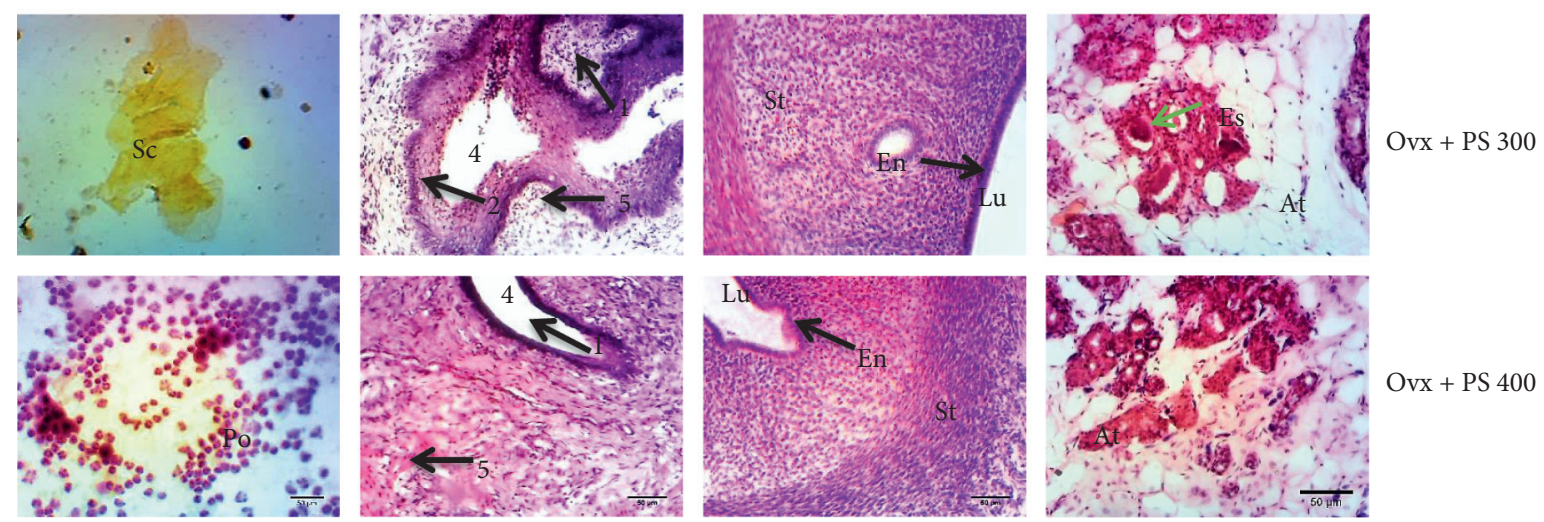

FIgURe 4: Microphotographies of vaginal cytology (100x, Papanicolaou) and the microarchitecture of vagina, uterus, and mammary gland (HE, 100x) after 3-days treatment with Pterocarpus soyauxii heartwood extract. PS $=$ P. soyauxii; vaginal cytology: $\mathbf{S c}=$ superficial cell; $\mathbf{I c}=$ intermediate cell; $\mathbf{P o}=$ polynuclear; $\mathbf{P c}=$ parabasal cell; vagina: $\mathbf{1}=$ Stratum germinativum $; \mathbf{2}=$ Stratum granulosum, $\mathbf{3}=$ Stratum corneum, $\mathbf{4}$ = lumen, $\mathbf{5}$ = chorion, uterus: Lu = uterine lumen; $\mathbf{E n}=$ endometrium; $\mathbf{S t}=$ myometrium; $\mathbf{m a m m a r y}$ gland: $\mathbf{A t}=$ adipose tissue; Es = eosinophilic secretion; $\mathbf{C a}=$ cell layer of the acinus. 


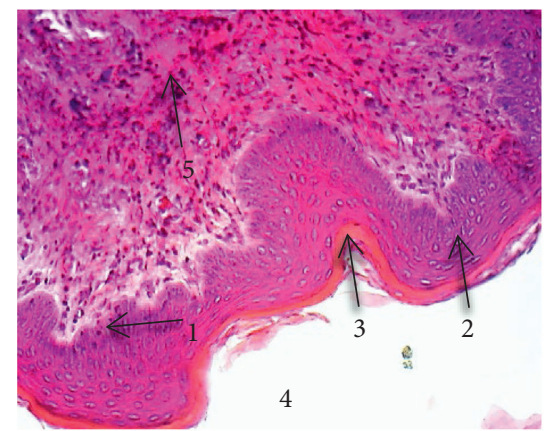

$\mathrm{SHAM}+\mathrm{H}_{2} \mathrm{O}$

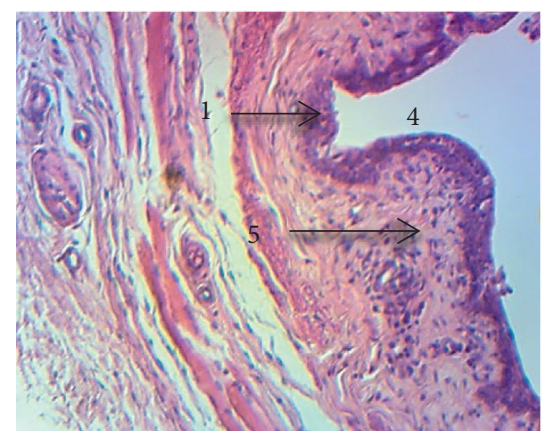

Ovx + PS 100

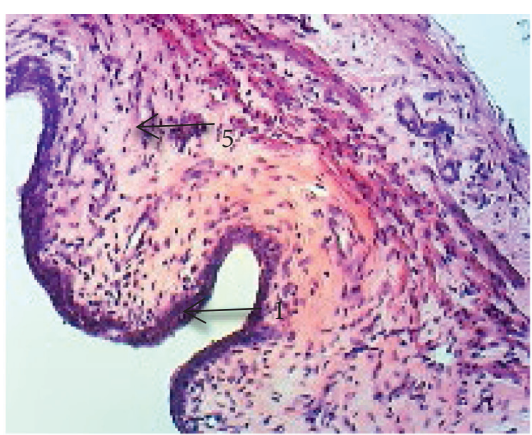

$\mathrm{Ovx}+\mathrm{H}_{2} \mathrm{O}$

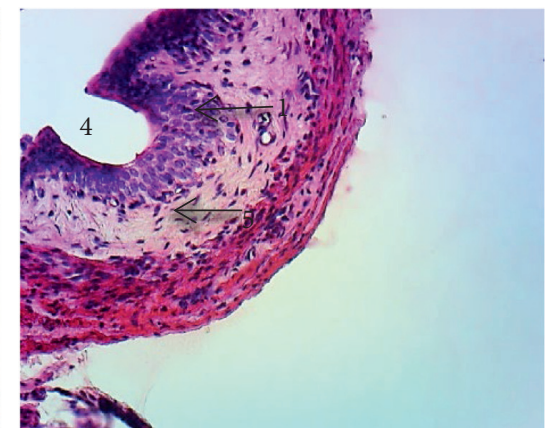

Ovx + PS 200

(a)

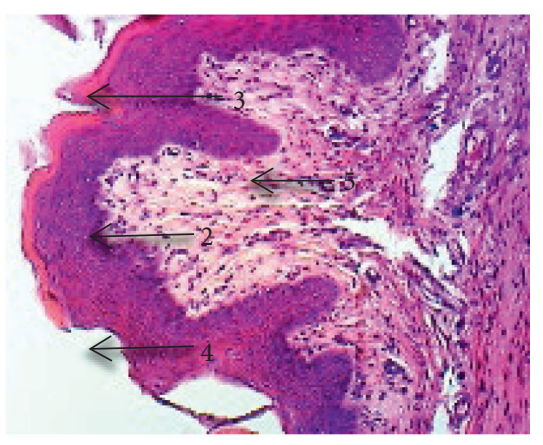

$\mathrm{Ovx}+\mathrm{E}_{2} \mathrm{~V}$

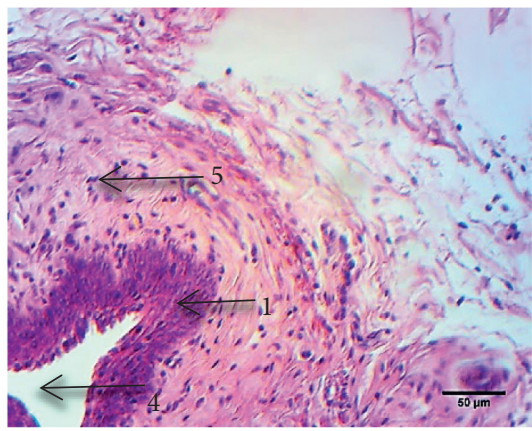

Ovx + PS 300

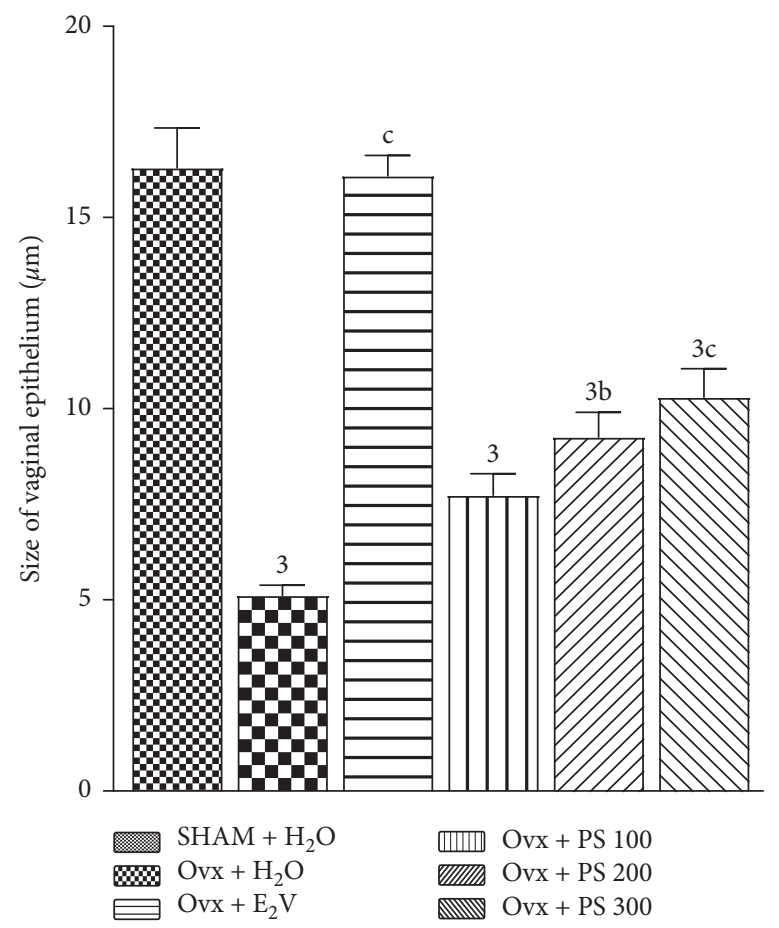

(b)

FIGURE 5: Effects of a 28-day treatment of with PS on vaginal epithelium (100x, haematoxylin-eosin). ${ }^{3} p<0.001$, significant difference compared to sham-operated control; ${ }^{b} p<0.01 ;{ }^{c} p<0.001$, significant difference compared to Ovx control. $1=$ Stratum germinativum; $\mathbf{2}=$ Stratum granulosum, $\mathbf{3}=$ Stratum corneum, $\mathbf{4}=$ lumen, $\mathbf{5}=$ chorion.

dependent tissues characterized firstly by a decrease of uterus relative weight, epithelial height, and protein level, and secondly by a decrease of vagina epithelial height as well as a decrease of mammary acini diameter and a lack of eosinophilic secretions in acini lumen. These effects could be attributed to ovarian loss. Indeed, ovaries estradiol 


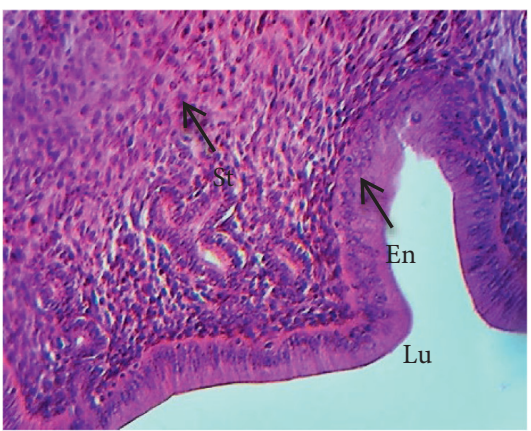

$\mathrm{SHAM}+\mathrm{H}_{2} \mathrm{O}$

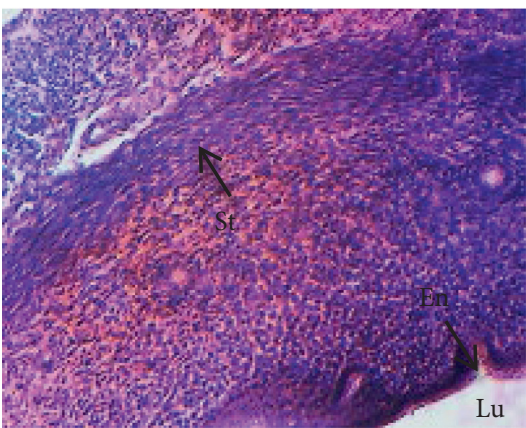

Ovx + PS 100

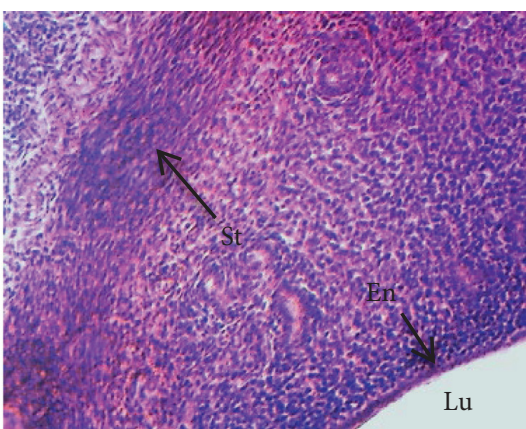

$\mathrm{Ovx}+\mathrm{H}_{2} \mathrm{O}$

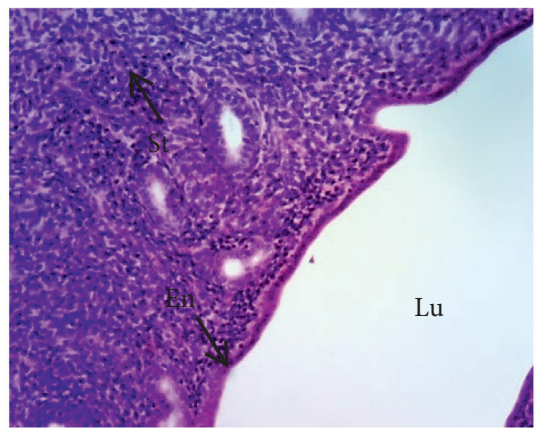

Ovx + PS 200

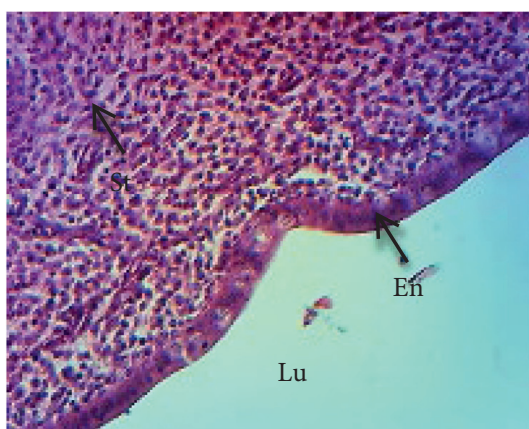

$\mathrm{Ovx}+\mathrm{E}_{2} \mathrm{~V}$

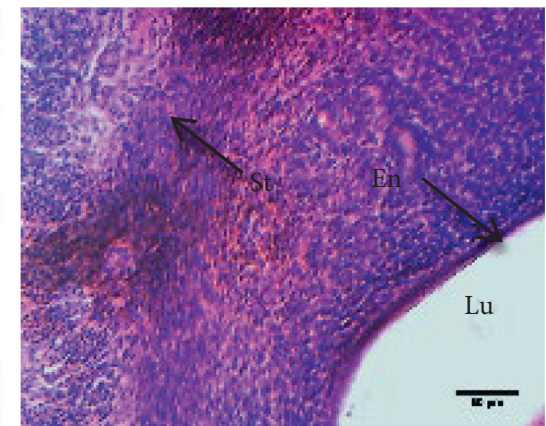

Ovx + PS 300

(a)

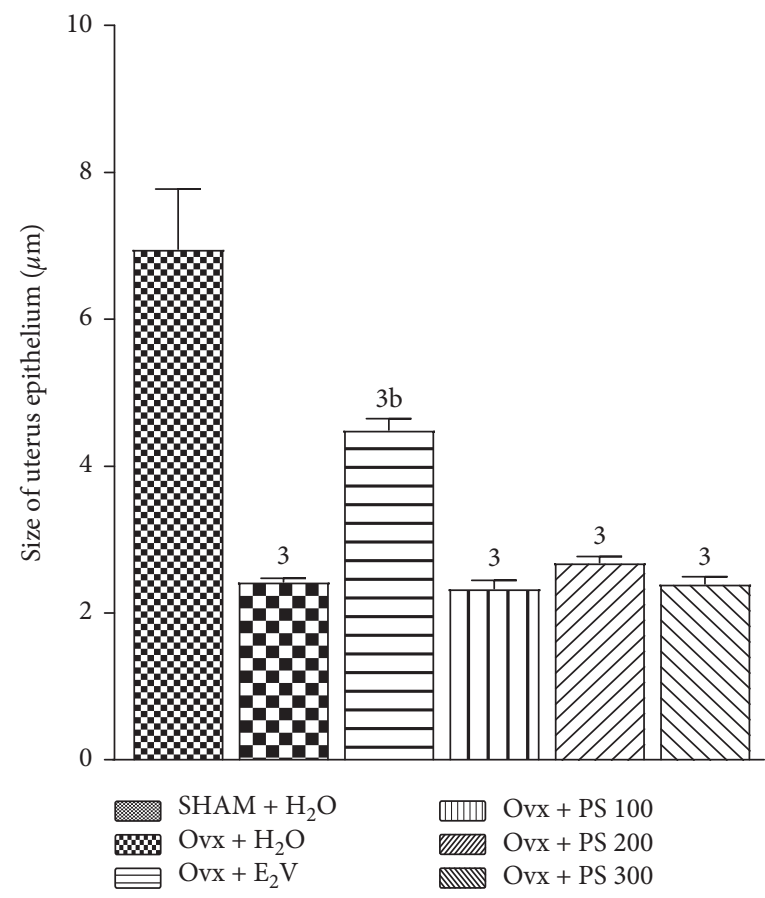

(b)

Figure 6: Effects of a 28-day treatment with P. soyauxii on uterine epithelium (100X, haematoxylin-eosin). ${ }^{3} p<0.001$, significant difference compared to sham-operated control; ${ }^{\mathrm{b}} p<0.01$, significant difference compared to Ovx rats treated with distilled water. PS $=$ P. soyauxii; $\mathbf{L u}=$ uterine lumen; $\mathbf{E n}=$ endometrium; $\mathbf{S t}=$ myometrium .

normally supplies dynamic development of estrogen-dependent tissues via a proliferative activity involving estrogen receptors [43]. The 28-days treatment with
Pterocarpus soyauxii aqueous extract resulted in stratification and an increase of vagina epithelial height without noticeable effects on mammary gland and uterus. Effect on 


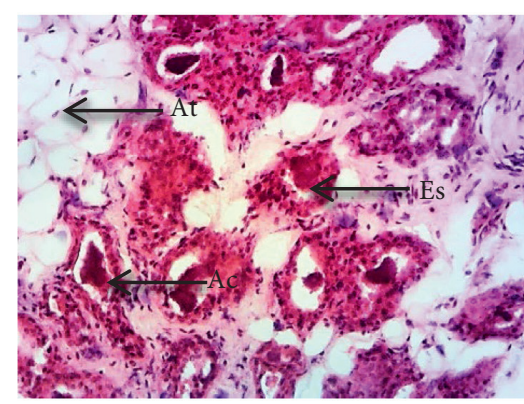

$\mathrm{SHAM}+\mathrm{H}_{2} \mathrm{O}$

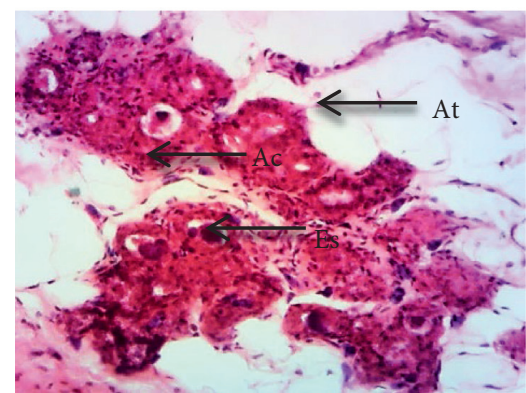

Ovx + PS 100

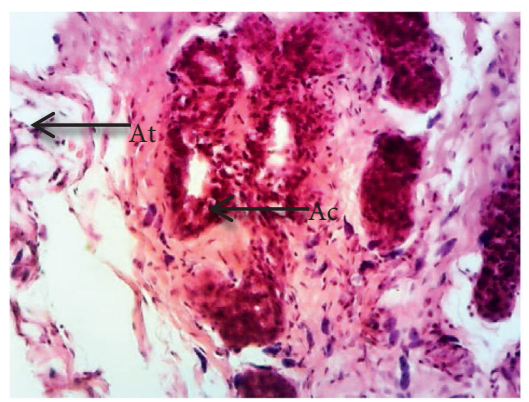

$\mathrm{Ovx}+\mathrm{H}_{2} \mathrm{O}$

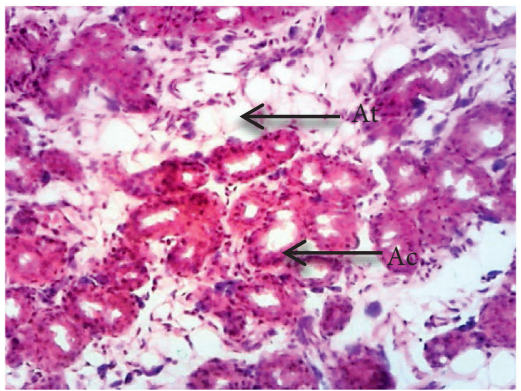

Ovx + PS 200

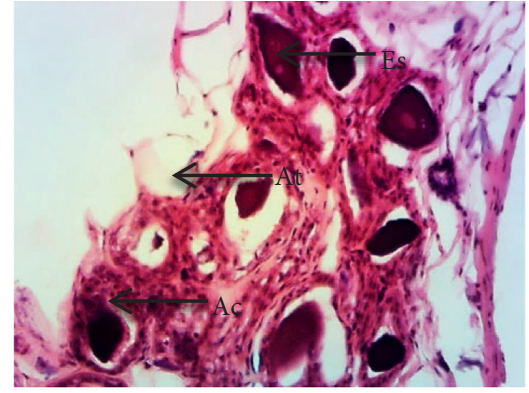

$\mathrm{Ovx}+\mathrm{E}_{2} \mathrm{~V}$

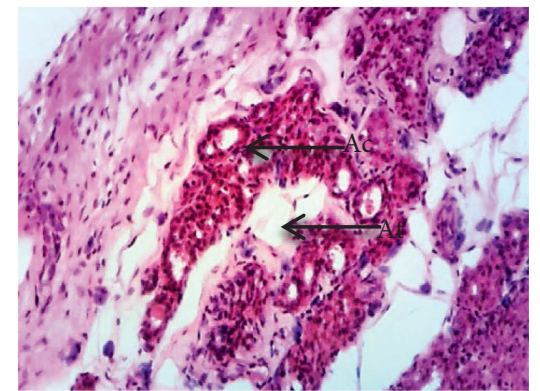

Ovx + PS 300

FIGURE 7: Effect of a 28-day treatment with PS on mammary gland (100×, haematoxylin-eosin) showing the differentiation in Ovx rats. At $=$ adipose tissue; $\mathbf{E s}=$ eosinophilic secretion; $\mathbf{C a}=$ cell layer of the acinus. (a) SHAM $+\mathrm{H}_{2} \mathrm{O}$. (b) Ovx $+\mathrm{H}_{2} \mathrm{O}$. (c) $\mathrm{Ovx}+\mathrm{E}_{2} \mathrm{~V}$. (d) Ovx $+\mathrm{PS}$ 100. (e) Ovx + PS 200. (f) Ovx + PS 300 .

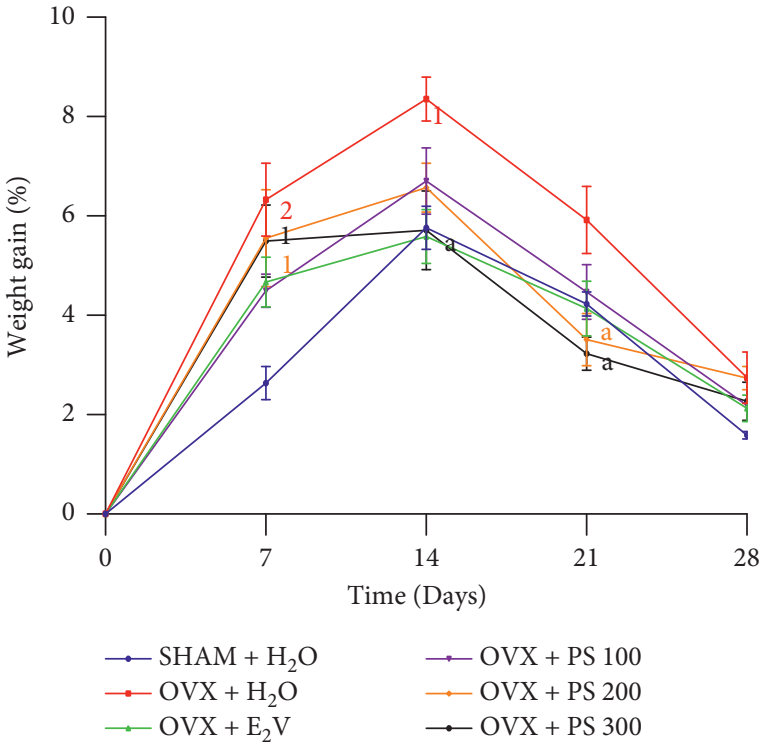

(a)

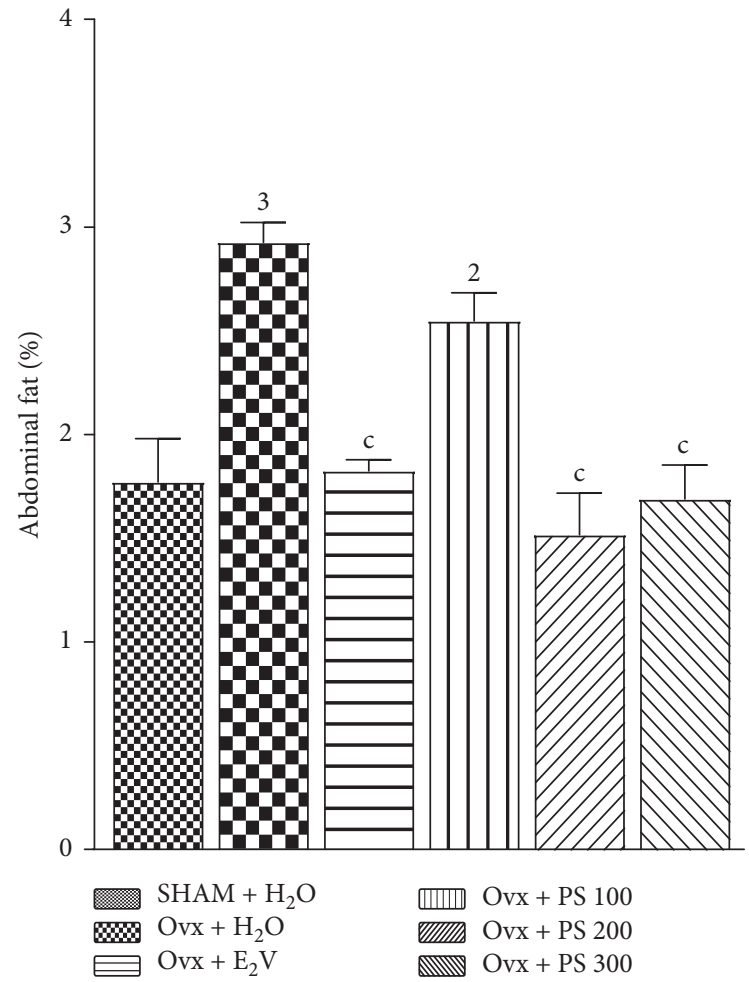

(b)

Figure 8: Effects of a 28-day P. soyauxii treatment on weight gain (a) and abdominal fat (b). ${ }^{1} p<0.05 ;{ }^{2} p<0.01 ;{ }^{3} p<0.001$, significant difference compared to sham-operated control; ${ }^{\mathrm{a}} p<0.05 ;{ }^{\mathrm{b}} p<0.01 ;{ }^{\mathrm{c}} p<0.001$, significant difference compared to Ovx control; PS $=P$. soyauxii. 


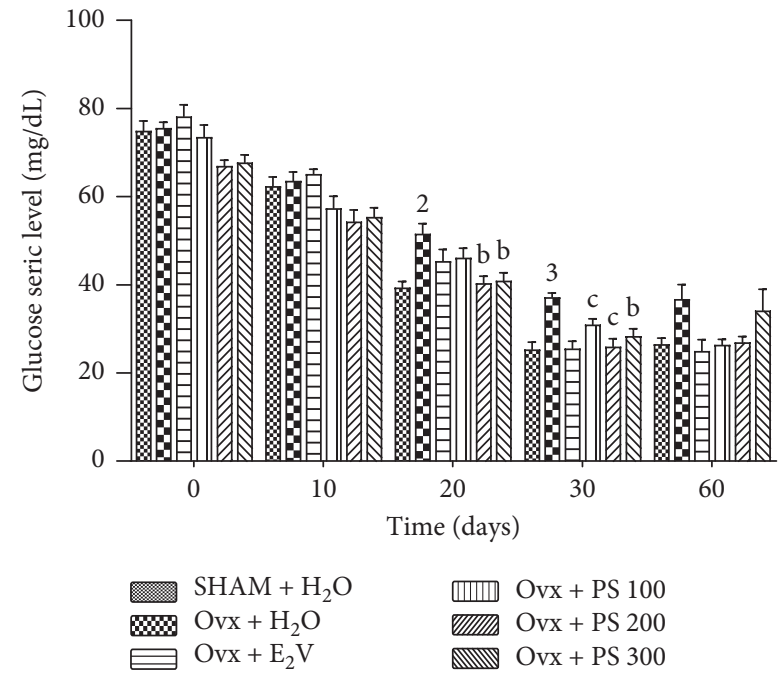

Figure 9: Effects of a 21-day treatment with $P$. soyauxii on serum glucose levels during insulin resistance test. ${ }^{1} p<0.05 ;{ }^{2} p<0.01 ;{ }^{3} p<0.001$, significant difference compared to sham-operated control; ${ }^{\mathrm{a}} p<0.05 ;{ }^{\mathrm{b}} p<0.01 ;{ }^{\mathrm{c}} p<0.001$, significant difference compared to Ovx control; PS $=P$. soyauxii.

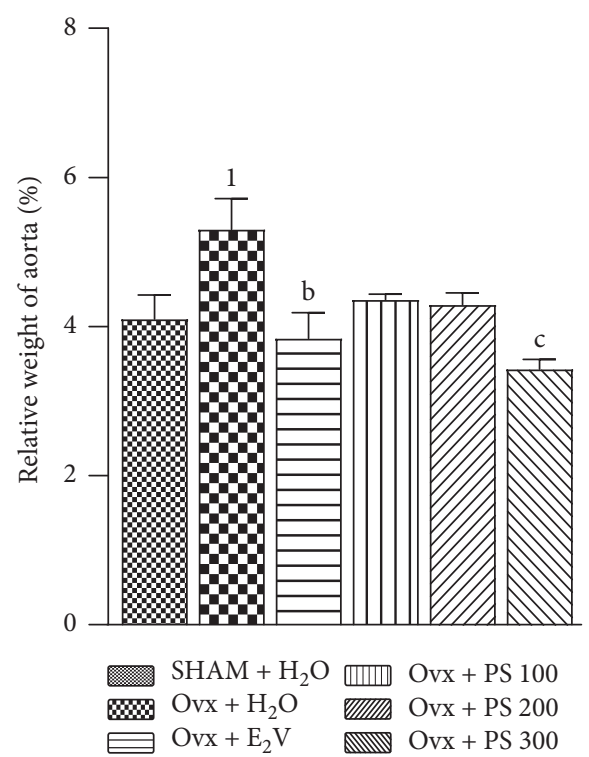

(a)

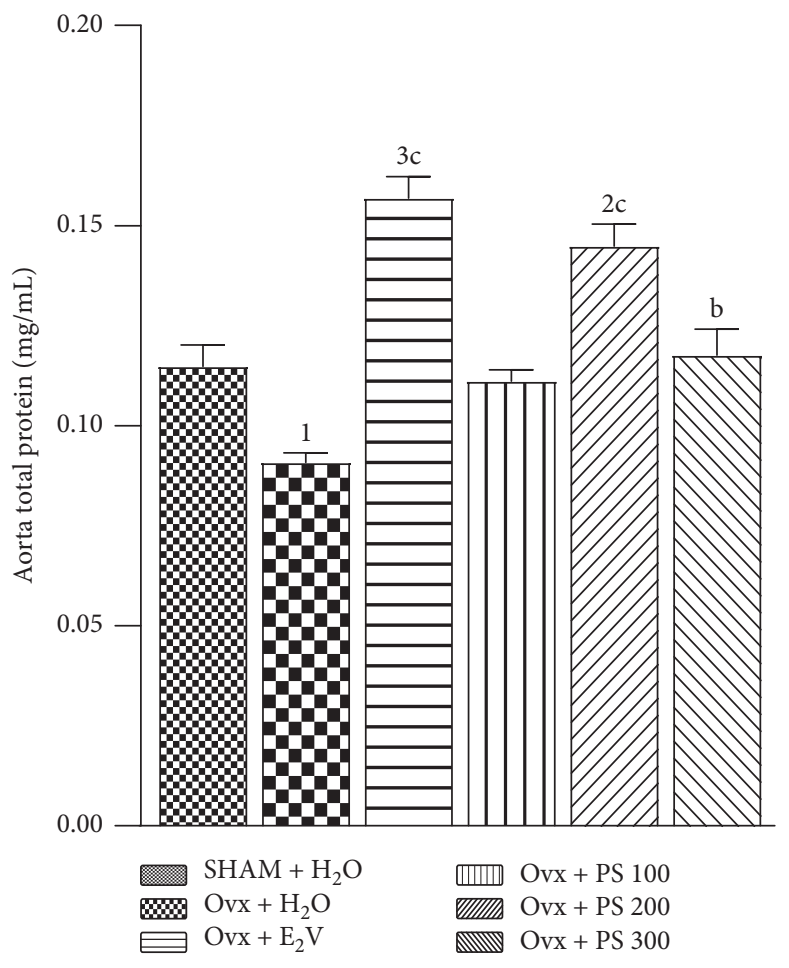

(b)

Figure 10: Effects of a 28-day treatment with P. soyauxii on fresh aorta weight (a) and aorta total protein levels (b). $1 p<0.05 ;{ }^{2} p<0.01$; ${ }^{3} p<0.001$, significant difference compared to sham-operated control; ${ }^{\mathrm{b}} p<0.01 ;{ }^{\mathrm{c}} p<0.001$, significant difference compared to Ovx control.

TABle 4: Effects of a 28-day treatment with P. soyauxii on lipid profile.

\begin{tabular}{lcccccc}
\hline Groups parameters & Sham $+\mathrm{H}_{2} \mathrm{O}$ & OVX $+\mathrm{H}_{2} \mathrm{O}$ & OVX $+\mathrm{E}_{2} \mathrm{~V}$ & OVX + PS 100 & OVX + PS 200 & OVX + PS 300 \\
\hline TC $(\mathrm{mmol} / \mathrm{L})$ & $1.43 \pm 0.03$ & $1.85 \pm 0.03^{3}$ & $1.56 \pm 0.05^{\mathrm{c}}$ & $1.80 \pm 0.03^{3}$ & $1.57 \pm 0.01^{\mathrm{b}}$ & $1.69 \pm 0.02$ \\
HDL-C $(\mathrm{mmol} / \mathrm{L})$ & $0.97 \pm 0.02$ & $0.55 \pm 0.01^{3}$ & $0.78 \pm 0.04^{1 \mathrm{~b}}$ & $0.54 \pm 0.02^{3}$ & $0.74 \pm 0.02^{2 \mathrm{a}}$ & $0.74 \pm 0.01^{2 \mathrm{a}}$ \\
LDL-C $(\mathrm{mmol} / \mathrm{L})$ & $0.32 \pm 0.05$ & $1.12 \pm 0.02^{3}$ & $0.56 \pm 0.07^{\mathrm{c}}$ & $0.61 \pm 0.06^{\mathrm{c}}$ & $0.71 \pm 0.03^{3 \mathrm{c}}$ & $0.60 \pm 0.06^{\mathrm{c}}$ \\
TG $(\mathrm{mmol} / \mathrm{L})$ & $0.63 \pm 0.02$ & $0.84 \pm 0.00^{3}$ & $0.68 \pm 0.02^{\mathrm{b}}$ & $0.73 \pm 0.03$ & $0.67 \pm 0.00^{\mathrm{b}}$ & $0.69 \pm 0.01^{\mathrm{b}}$ \\
VLDL $(\mathrm{mmol} / \mathrm{L})$ & $0.12 \pm 0.00$ & $0.16 \pm 0.00^{3}$ & $0.12 \pm 0.00^{\mathrm{c}}$ & $0.14 \pm 0.00$ & $0.13 \pm 0.00^{\mathrm{b}}$ & $0.14 \pm 0.00^{\mathrm{c}}$ \\
AI & $1.45 \pm 0.05$ & $3.31 \pm 0.05^{3}$ & $2.20 \pm 0.12^{3 \mathrm{c}}$ & $3.44 \pm 0.06$ & $2.24 \pm 0.08^{\mathrm{c}}$ & $2.17 \pm 0.13^{3 \mathrm{c}}$ \\
\hline
\end{tabular}

Values represent means $\pm \operatorname{SEM}(n=5) ;{ }^{1} p<0.05 ;{ }^{2} p<0.01 ;{ }^{3} p<0.001$, significant difference compared to sham-operated control; ${ }^{\mathrm{a}} p<0.05 ;{ }^{\mathrm{b}} p<0.01$; ${ }^{c} p<0.001$, significant difference compared to Ovx control; PS $=P$. soyauxii. 


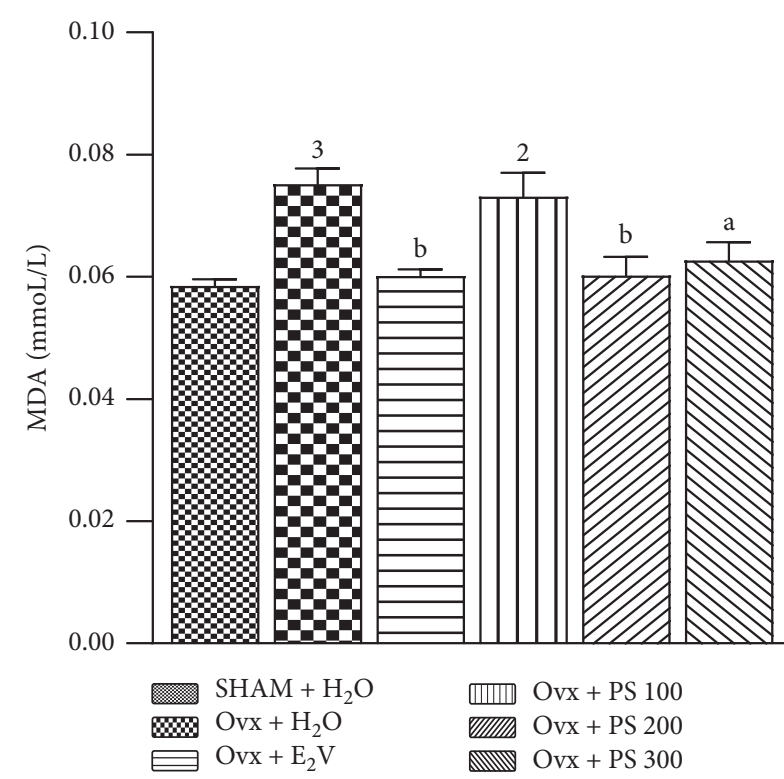

(a)

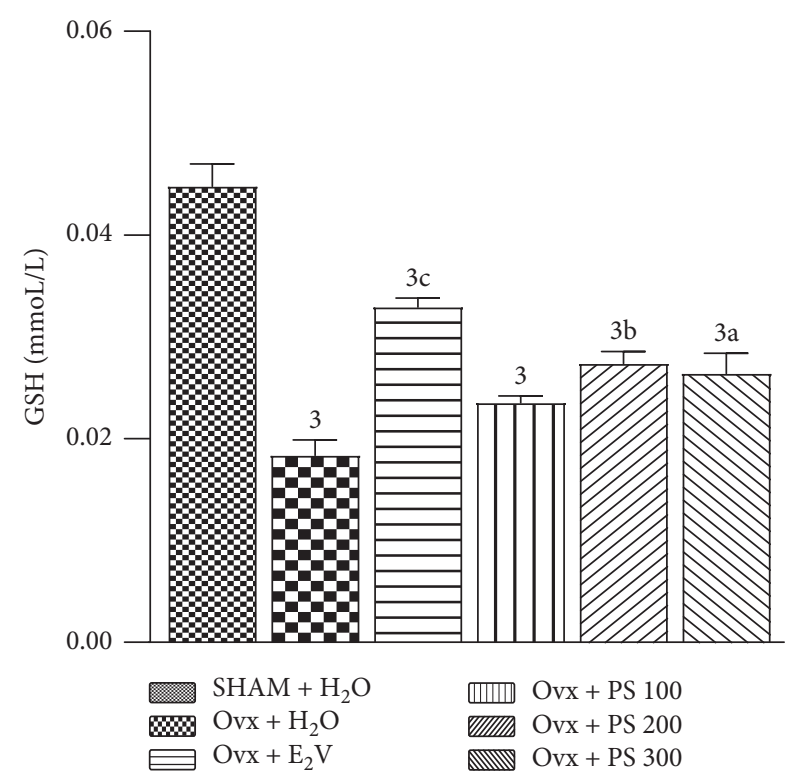

(b)

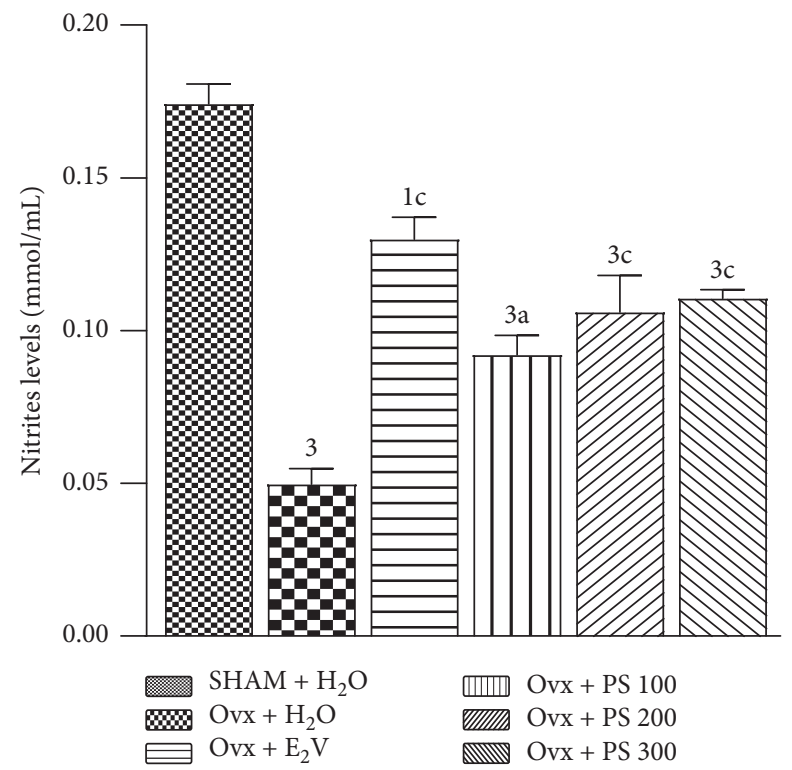

(c)

Figure 11: Effects of a 28-day treatment with P. soyauxii on MDA (a), GSH (b), and nitrites (c) aorta levels. ${ }^{1} p<0.05 ;{ }^{2} p<0.01 ;{ }^{3} p<0.001$, significant difference compared to sham-operated control; ${ }^{\mathrm{a}} p<0.05 ;{ }^{\mathrm{b}} p<0.01 ;{ }^{\mathrm{c}} p<0.001$, significant difference compared to Ovx control; PS $=P$. soyauxii $\mathbf{M D A}=$ Malondialdehyde; $\mathbf{G S H}=$ reduced glutathione.

vagina after 28-days treatment could be due to linoleic acid, known as promoting vaginal cornification [44]. This lack of long-term action of the plant extract on mammary gland and uterus could reflect a potential selective effect, useful for preventing estrogen-dependent cancers. In addition, LCMS analysis revealed the presence in the plant extract of mono(2-ethylhexyl) phthalate (MEHP) and $3^{\prime}, 5^{\prime}$-dimethoxy-4-Stilbenol or pterostilbene which are known as selective estrogen receptor modulators (SERM). This differing agonist or antagonist effects at the estrogen receptor in different tissues of pterostilbene contained in the plant extract can prevent hormone responsive cancers $[45,46]$.
In addition to genital atrophy, oophorectomy resulted in an increase of relative weight of abdominal fat, weight gain, and insulin resistance correlated with dyslipidaemia and an increased atherogenic index, similar to studies carried by Somayeh et al. [47] and Dzeufiet et al. [11]. Indeed, estrogen deficiency increases lipoprotein lipase activity, leading to blood fatty acids accumulation, and thus dyslipidaemia [48]. According to Wade [49], estrogen negatively regulates food intake and weight gain. Thereby, increased body weight and abdominal fat in ovariectomized rats in this study could be due to high food intake and fat accumulation in adipose tissue [50]. It has also been established that free radical 


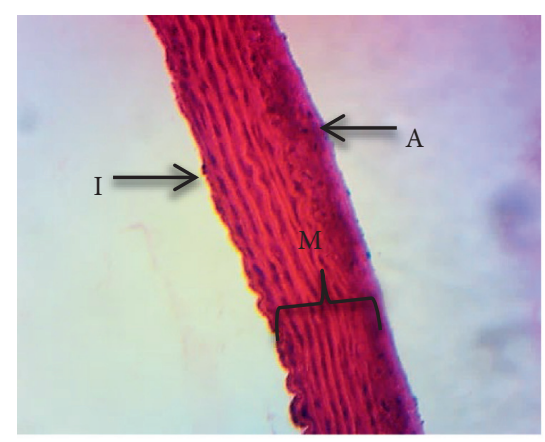

$\mathrm{SHAM}+\mathrm{H}_{2} \mathrm{O}$

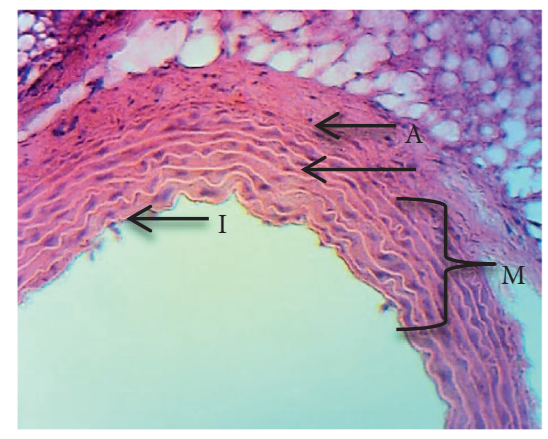

Ovx + PS 100

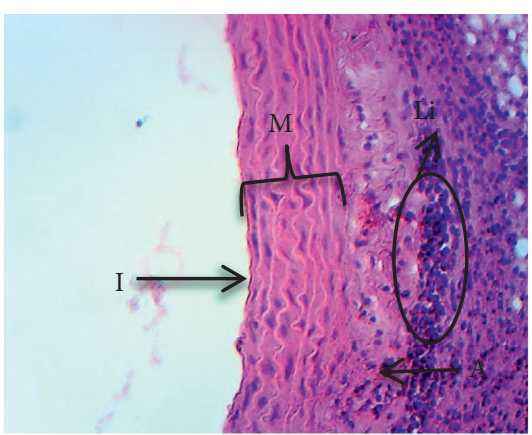

$\mathrm{Ovx}+\mathrm{H}_{2} \mathrm{O}$

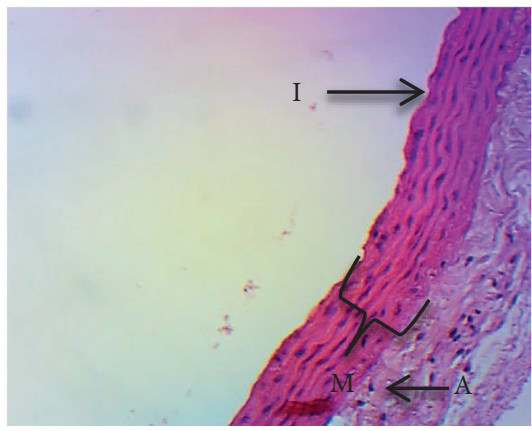

Ovx + PS 200

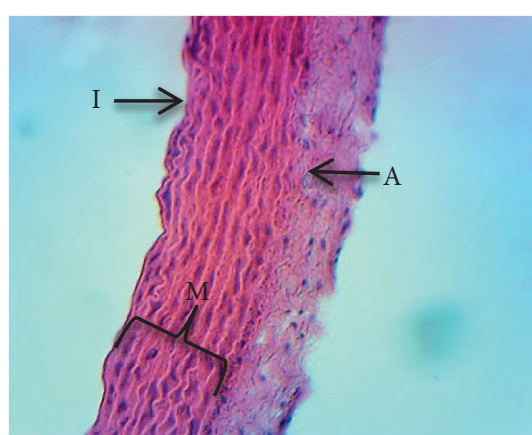

$\mathrm{Ovx}+\mathrm{E}_{2} \mathrm{~V}$

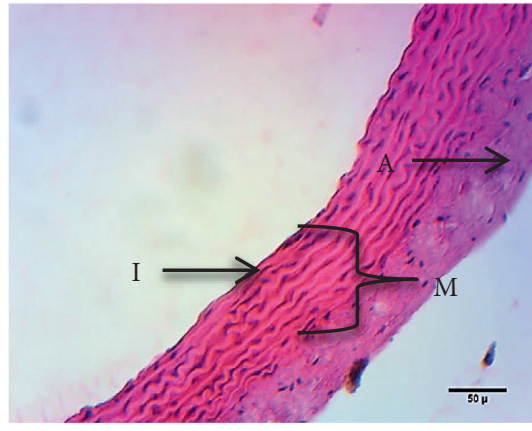

Ovx + PS 300

(a)

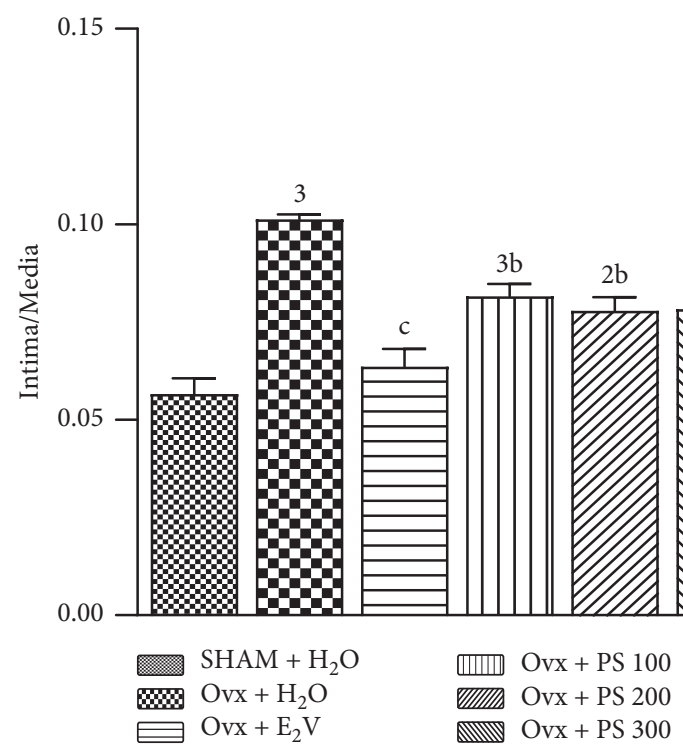

(b)

Figure 12: Effects of P. soyauxii 28-day treatment on aorta (100×, haematoxylin-eosin). PS = P. soyauxii; (I) intima; (M): media; (A): adventitia; $\mathbf{L i}=$ leukocyte infiltration.

oxidation of LDL cholesterol leads to atherosclerosis [11]. In the present study, the increase of atherogenic index is associated with oxidative stress in ovariectomized rats. Indeed, in addition to an increased LDL cholesterol, ovariectomized rats exhibited a high lipid peroxidation via an increase of MDA level. They showed also a decrease of GSH concentration which characterized an oxidative stress. Compared to Ovx control, $P$. soyauxii extract significantly reduced abdominal fat weight and body weights, insulin resistance, and dyslipidaemia. These effects could be due to the $3^{\prime}, 5^{\prime}$ dimethoxy-4-stilbenol also called pterostilbene which was revealed by LC-MS analysis. Indeed, pterostilbene is known for its antiadipogenic and hypotriglyceridemic properties through inhibition of proliferation and differentiation of 3T3-L1 cells into adipocytes, fatty acids accumulation, and expression of Diacylglycerol O-acyltransferase 1 (DGAT1) 
which supply triglycerides synthesis. In addition, pterostilbene is known to reduce expression of Peroxisome Proliferator Activated Receptors $\gamma(\operatorname{PPAR} \gamma)$ involved in the starting of insulin resistance and dyslipidaemia [51, 52].

Oophorectomy is associated with a high activity of nicotinamide adenine dinucleotide phosphate (NADPH) oxidase, leading to the formation of free radicals in the mitochondria. The high production of free radicals is a major contributor in the pathogenesis of atherosclerosis through LDL cholesterol oxidation [53], starting process of endothelial dysfunction leading to a decreased nitrogen monoxide levels in aorta. This atherogenic process constitutes an inflammatory state materialized in this work by leukocyte infiltration on aortic sections in Ovx control. The treatment with plant extract improved the oxidative status as well as leukocyte infiltration in the aorta at 100,200 , and $300 \mathrm{mg} / \mathrm{kg}$. Indeed, pterostilbene is known to exert antioxidant and antiinflammatory activities. They decreased expression of NADPH oxidase and inactivation of NF- $\kappa \mathrm{B}$ via a downregulation of Toll-like 5 receptors [54].

\section{Conclusions}

Sixteen-week bilateral oophorectomy induced postmenopausal symptoms in rats like vagina atrophy, dyslipidaemia, insulin resistance, weight gain, and oxidative stress. $P$. soyauxii aqueous extract contains mono(2-ethylhexyl) phthalate, cembrene, $3^{\prime}, 5^{\prime}$-dimethoxy-4-stilbenol, and linoleic acid. Furthermore, this extract is able to exhibit estrogenic and antioxidant activities which are probably responsible of the prevention of postmenopausal symptoms. There is a need to evaluate different pathways involved by secondary metabolites of this extract on postmenopausal symptoms.

\section{Abbreviation}

ABTS:

2,2'-Azinobis-3- ethylbenzothiazoline-6sulfonic acid

AI: $\quad$ Atherogenic index

DAD: Diode array detector

DGAT1: Diacylglycerol O-acyltransferase 1

DPPH: 1,1-Diphenyl-2-picrylhydrazyl

$\mathrm{E}_{2} \mathrm{~V}: \quad$ Estradiol valerate

FRAP: $\quad$ Ferric-reducing antioxidant power

GSH: $\quad$ Reduced glutathione

HED: Human equivalent dose

HDL-C: High-density lipoprotein cholesterol

HRT: Hormone replacement therapy

IC50: Inhibitory concentration 50

ITT: Insulin tolerance test

LC-MS: Liquid chromatography-mass spectrometry

LDL-C: Low-density lipoprotein cholesterol

MDA: Malondialdehyde

MEHP: Mono(2-ethylhexyl) phthalate

NF- $\kappa$ B: Nuclear factor kappa-light-chain-enhancer of activated B cells

Ovx: $\quad$ Ovariectomized animals

PPAR $\gamma$ : Peroxisome proliferator activated receptors $\gamma$
PS: $\quad$ Pterocarpus soyauxii

ROS: $\quad$ Reactive oxygen species

SERM: Selective estrogen receptor modulators

TC: Total cholesterol

TG: $\quad$ Triglycerides

TPTZ: 2,4,6-Tri(2-pyridyl)-s-triazine

UHPLC- Ultra-High-Performance Liquid

MS: $\quad$ Chromatography tandem mass spectrometry

VLDL-C: Very-low-density lipoprotein cholesterol.

\section{Data Availability}

The data are available upon request.

\section{Conflicts of Interest}

The authors declare that there are no conflicts of interest.

\section{Authors' Contributions}

O. P. Emmanuel, N. M. Chantal, and M. N. Lohik carried out the experiments. M. N. Y. Sandrine, B. A. G. Ronald, and K. T. R. Bernes were involved in histological analysis. N. Michel and N. F. Rodrigue performed biochemical analyses. D. D. P. Désiré, K. Pierre, and B. D. Claude designed the study. All the authors were involved in the draft and review of the manuscript.

\section{Acknowledgments}

The authors appreciate the staff of the Laboratory of Animal Physiology, University of Yaoundé 1, for their valuable help. The authors are also grateful for French association PCD (Pathologie Cytologie Développement) for providing histological reagents.

\section{References}

[1] J. P. G. Camporez, F. R. Jornayvaz, H.-Y. Lee et al., "Cellular mechanism by which estradiol protects female ovariectomized mice from high-fat diet-induced hepatic and muscle insulin resistance," Endocrinology, vol. 154, no. 3, pp. 1021-1028, 2013.

[2] V. Bittner, "Menopause, age, and cardiovascular risk," Journal of the American College of Cardiology, vol. 54, no. 25, pp. 2374-2375, 2009.

[3] D. J. Betteridge, "What is oxidative stress?" Metabolism, vol. 49, no. 2-1, pp. 3-8, 2000.

[4] F. Giacco, M. Brownlee, and A. M. Schmidt, "Oxidative stress and diabetic complications," Circulation Research, vol. 107, no. 9, pp. 1058-1070, 2010.

[5] J. S. Bhatti, S. Kumar, M. Vijayan, G. K. Bhatti, and P. H. Reddy, "Therapeutic strategies for mitochondrial dysfunction and oxidative stress in age-related metabolic disorders," Progress in Molecular Biology and Translational Science, vol. 146, pp. 13-46, 2017.

[6] C. M. Sena, A. M. Pereira, and R. Seiça, "Endothelial dysfunction- a major mediator of diabetic vascular disease," Biochimica et Biophysica Acta, vol. 1832, no. 12, pp. 22162231, 2013. 
[7] M. Rodriguez-Porcel, A. R. Chade, and J. D. Miller, "Studies on atherosclerosis. Oxidative stress in applied basic research and clinical practice," 2017.

[8] British Menopause Society, "HRT: Benefits and risks Women's health concern fact sheet. Informa.tion for women," 2020.

[9] N. R. Cook, C. M. Albert, J. M. Gaziano et al., “A randomized factorial trial of vitamins $\mathrm{C}$ and $\mathrm{E}$ and beta carotene in the secondary prevention of cardiovascular events in women," Archives of Internal Medicine, vol. 167, no. 15, pp. 1610-1618, 2007.

[10] S. Mitra, A. Deshmukh, R. Sachdeva, J. Lu, and J. L. Mehta, "Oxidized low-density lipoprotein and atherosclerosis implications in antioxidant therapy," The American Journal of the Medical Sciences, vol. 342, no. 2, pp. 135-142, 2011.

[11] D. P. D. Dzeufiet, N. Y. S. Mengue, D. C. Bilanda et al., "In vivo estrogenic-like activities of Gouania Longipetala Hemsl. (Rhamnaceae) bark extracts in a post-menopause-like model of ovariectomized Wistar rats," Journal of Ethnopharmacology, vol. 168, pp. 122-128, 2015.

[12] M. C. Ngoungouré, D. C. Bilanda, D. P. D. Dzeufiet et al., "Oral acute toxicity and estrogenic-like effects of the aqueous extract of Anthocleista schweinfurthii Gilg (Loganiaceae)," Pharmacologia, vol. 8, pp. 9-17, 2017.

[13] M. Wilson, V. Konda, K. Heidt, T. Rathinasabapathy, A. Desai, and S. Komarnytsky, "Rheum rhaponticum root extract improves vasomotor menopausal symptoms and estrogen-regulated targets in ovariectomized rat model," International Journal of Molecular Sciences, vol. 22, no. 3, pp. 1-12, 2021.

[14] S. Djiogue, M. Halabalaki, X. Alexi et al., "Isoflavonoids from Erythrina poeppigiana: evaluation of their binding affinity for the estrogen receptor," Journal of Natural Products, vol. 72, no. 9, pp. 1603-1607, 2009.

[15] C. B. Tempfer, G. Froese, G. Heinze, E.-K. Bentz, L. A. Hefler, and J. C. Huber, "Side effects of phytoestrogens: a metaanalysis of randomized trials," The American Journal of Medicine, vol. 122, no. 10, pp. 939-946, 2009.

[16] I. Brémaud, N. Amusant, K. Minato, J. Gril, and B. Thibaut, "Effect of extractives on vibrational properties of african padauk (Pterocarpus soyauxii Taub.)," Wood Science and Technology, vol. 45, no. 3, pp. 461-472, 2011.

[17] J.-B. T. Saha, D. Abia, S. Dumarçay et al., "Antioxidant activities, total phenolic contents and chemical compositions of extracts from four Cameroonian woods: padouk (Pterocarpus soyauxii Taubb), tali (Erythrophleum suaveolens), moabi (Baillonella toxisperma), and movingui (Distemonanthus benthamianus)," Industrial Crops and Products, vol. 41, no. 1, pp. 71-77, 2013.

[18] R. T. O. Kala, "Tollefsbol, A novel combinatorial epigenetic therapy using resveratrol and pterostilbene for restoring estrogen receptor- $\alpha(\mathrm{ER} \alpha)$ expression in $\mathrm{ER} \alpha$-negative breast cancer cells," PLos One, vol. 11, no. 5, pp. 1-17, 2016.

[19] A. Nair and S. Jacob, "A simple practice guide for dose conversion between animals and human," Journal of Basic and Clinical Pharmacy, vol. 7, no. 2, pp. 27-31, 2016.

[20] R. B. Broadhurst and W. T. Jones, "Analysis of condensed tannins using acidified vanillin," Journal of the Science of Food and Agriculture, vol. 29, no. 9, pp. 788-794, 1978.

[21] V. L. Singleton and J. A. Rossi, "Colorimetry of total phenolics with phosphomolybdic-phosphotungstic acid reagents," American Journal of Enology and Viticulture, vol. 37, pp. 144-158, 1965.
[22] J. Zhishen, T. Mengcheng, and W. Jianming, "The determination of flavonoid contents in mulberry and their scavenging effects on superoxide radicals," Food Chemistry, vol. 64, no. 4, pp. 555-559, 1999.

[23] L. L. Mensor, F. S. Menezes, G. G. Leitão et al., "Screening of Brazilian plant extracts for antioxidant activity by the use of DPPH free radical method," Phytotherapy Research, vol. 15, no. 2, pp. 127-130, 2001.

[24] I. F. F. Benzie and J. J. Strain, "The ferric reducing ability of plasma (FRAP) as a measure of "antioxidant power:": the FRAP assay," Analytical Biochemistry, vol. 239, no. 1, pp. 70-76, 1996.

[25] R. Re, N. Pellegrini, A. Proteggente, A. Pannala, M. Yang, and C. Rice-Evans, "Antioxidant activity applying an improved ABTS radical cation decolorization assay," Free Radical Biology and Medicine, vol. 26, no. 9-10, pp. 1231-1237, 1999.

[26] Éditions OCDE. n440, Bio-essai utérotrophique chez les rongeurs: Essai de dépistage à court terme des propriétés oestrogéniques, Lignes directrices de l'OCDE pour les essais de produits chimiques, Éditions OCDE, Paris, France, 2007.

[27] W. T. Friedewald, R. I. Levy, and D. S. Fredrickson, "Estimation of the concentration of low-density lipoprotein cholesterol in plasma, without use of the preparative ultracentrifuge," Clinical Chemistry, vol. 18, no. 6, pp. 499-502, 1972.

[28] N. Akhtar, M. K. Srivastava, and R. B. Raizada, “Assessment of chlorpyrifos toxicity on certain organs in rat Rattus norvegicus," Journal of Environmental Biology, vol. 30, no. 6, pp. 1047-1053, 2009.

[29] J. F. Fortier and R. Hould, Histotechnologie: Théories et procédés, CCDMD edition, Paris, France, 2003.

[30] K. M. Wilbur, F. Bernheim, and O. W. Shapiro, "The Thiobarbituric acid reagent as a test for the oxidation of unsaturated fatty acids by various agents," Archives of Biochemistry and Biophysics, vol. 24, no. 2, pp. 305-313, 1949.

[31] G. L. Ellman, "Tissue sulfhydryl groups," Archives of Biochemistry and Biophysics, vol. 82, no. 1, pp. 70-77, 1959.

[32] L. C. Green, D. A. Wagner, J. Glogowski, P. L. Skipper, J. S. Wishnok, and S. R. Tannenbaum, "Analysis of nitrate, nitrite, and $[15 \mathrm{~N}]$ nitrate in biological fluids," Analytical Biochemistry, vol. 126, no. 1, pp. 131-138, 1982.

[33] M. C. Ngoungoure, D. P. D. Dzeufiet DPD, D. C. Bilanda et al., "Neuroprotective effects of the Anthocleista Schweinfurthii Gilg. (Loganiaceae) stem bark extract in postmenopause-like model of ovariectomized wistar rats," Journal of Complementary and Integrative Medicine, vol. 16, no. 1, pp. 1-7, 2019.

[34] D. Njamen, N. C. B. Magne, and G. Vollmer, "Effects of the extracts of some tropical medicinal plants on estrogen inducible yeast and Ishikawa screens, and on ovariectomized Wistar rats," Die Pharmazie, vol. 63, no. 2, pp. 164-168, 2012.

[35] S. Zingue, N. C. B. Magne, C. Clyne, and D. Njamen, "Elucidation of underlying mechanisms by which Millettia macrophylla Benth induces its estrogenic activity," International Scholarly Research Notices, vol. 2014, Article ID 763781, 8 pages, 2014.

[36] S. Choi, T. Ha, J. Ahn et al., "Estrogenic activities of isoflavones and flavones and their structure-activity relationships," Planta Medica, vol. 74, no. 1, pp. 25-32, 2008.

[37] B. Lalithadevi, N. S. Muthiah, and S. N. Murty, "Antioxidant activity of conjugated linoleic acid," Asian Journal of Pharmaceutical and Clinical Research, vol. 11, no. 11, pp. 169-173, 2018. 
[38] A. Saffaryazdi, A. Ganjeali, and R. Farhoosh, "Variation in phenolic compounds, $\alpha$-linolenic acid and linoleic acid contents and antioxidant activity of purslane (Portulaca oleracea L.) during phenological growth stages," Physiology and Molecular Biology of Plants, vol. 26, pp. 1519-1529, 2020.

[39] A. Tchernof, M. D. Desmeules, C. Richard et al., "Ovarian hormone status and abdominal visceral adipose tissue metabolism," Journal of Clinical Endocrinology \& Metabolism, vol. 89, no. 7, pp. 3425-3430, 2004.

[40] I. Baeza, N. M. De Castro, L. Gimenez-Llort, and M. De la Fuente, "Ovariectomy, a model of menopause in rodents, causes a premature aging of the nervous and immune systems," Journal of Neuroimmunology, vol. 219, no. 1-2, pp. 90-99, 2010.

[41] M. C. Carr, "The emergence of the metabolic syndrome with menopause," Journal of Clinical Endocrinology \& Metabolism, vol. 88, no. 6, pp. 2404-2411, 2003.

[42] M.-E. Piche, S. J. Weisnagel, L. Corneau, A. Nadeau, J. Bergeron, and S. Lemieux, "Contribution of Abdominal Visceral Obesity and Insulin Resistance to the Cardiovascular Risk Profile of Postmenopausal Womenfile of postmenopausal women," Diabetes, vol. 54, no. 3, pp. 770-777, 2005.

[43] C. Heinemann and G. Reid, "Vaginal microbial diversity among postmenopausal women with and without hormone replacement therapy," Canadian Journal of Microbiology, vol. 51, no. 9, pp. 777-781, 2005.

[44] P. Saadat and A. L. Latiffah, "Supplementary health benefits of linoleic acid by improvement of vaginal cornification of ovariectomized rats," Advanced Pharmaceutical Bulletin, vol. 3, no. 1, pp. 31-36, 2013.

[45] K. Da-Hye, G. P. Chang, H. K. Sang, and J. K. Young, "The effects of mono-(2-ethylhexyl) phthalate (MEHP) on human estrogen receptor (her) and androgen receptor (har) by YES/ YAS in vitro Assay," Molecules, vol. 24, no. 8, pp. 1-10, 2019.

[46] P. Chi, H. Yiwang, L. Jun et al., "Estrogen receptor-a36 is involved in pterostilbene induced apoptosis and anti-proliferation in in vitro and in vivo breast cancer," PLos One, vol. 9, no. 8, pp. 1-8, 2014.

[47] K. Somayeh, Z. Samad, and B. Parvin, "Flavonoids fraction of Mespilus germanica alleviates insulin resistance in metabolic syndrome model of ovariectomized rats via reduction in tumor necrosis factor- $\alpha$," Journal of Menopausal Medicine, vol. 24, no. 3, pp. 169-175, 2018.

[48] M. Tamayo, H. Takuya, O. Masafumi et al., "Effects of estrogen on cardiovascular injury in ovariectomized female DahlS.ZLepr $^{\mathrm{fa}} /$ Lepr $^{\text {fa }}$ Rats as a new animal model of metabolic syndrome," Hypertension, vol. 59, no. 3, pp. 552-554, 2012.

[49] G. N. Wade, Sex hormones, regulatory behaviors and body weight, Academic press, New York, NY, USA, 1976.

[50] E. J. Roy and G. N. Wade, "Role of food intake in estradiolinduced body weight changes in female rats," Hormones and Behavior, vol. 8, no. 3, pp. 265-274, 1977.

[51] Y.-J. Seo, K.-J. Kim, E.-J. Koh, J. Choi, and B.-Y. Lee, “Antiadipogenesis mechanism of pterostilbene through the activation of heme oxygenase-1 in 3T3-L1 cells," Phytomedicine, vol. 33, pp. 7-13, 2017.

[52] J. R. Barry and M. R. Gerald, "PPAR- $\gamma$ agonists, insulin resistance and dyslipidemia: not a simple relationship," Clinical Lipidology, vol. 5, no. 4, pp. 509-525, 2010.

[53] M. A. Alyson, R. D. Grant, E. M. Anja, S. W. H. H. Harald, and S. G. Christopher, "Effect of gender on NADPH-oxidase activity, expression, and function in the cerebral circulation role of estrogen," Stroke, vol. 38, no. 7, pp. 2142-2149, 2007.
[54] W.-S. Lin, J. V. Leland, C.-T. Ho, and M.-H. Pan, "Occurrence, bioavailability, anti-inflammatory, and anticancer effects of pterostilbene," Journal of Agricultural and Food Chemistry, vol. 68, no. 46, pp. 12788-12799, 2020. 